\title{
QUANTITATIVE GOALS FOR MONETARY POLICY
}

by Antonio Fatás,

llian Mihov

and Andrew K. Rose 
EUROPEAN CENTRAL BANK

\title{
WORKING PAPER SERIES
}

NO 6 I5 / APRIL 2006

\author{
INTERNATIONAL RESEARCH \\ FORUM ON MONETARY POLICY

\section{QUANTITATIVE GOALS FOR MONETARY POLICY'}

\author{
by Antonio Fatás', \\ llian Mihov ${ }^{3}$
}

and Andrew K. Rose ${ }^{4}$

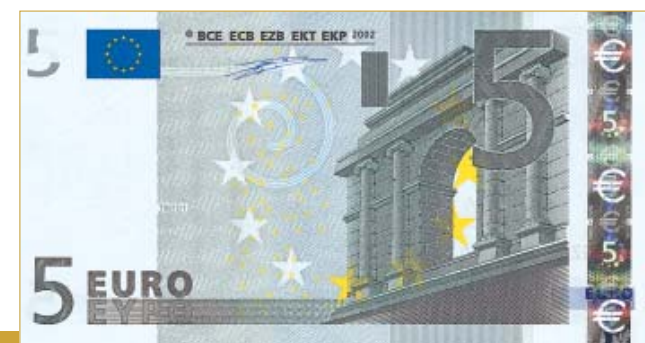

In 2006 all ECB

publications

will feature

a motif taken

from the

$€ 5$ banknote.

This paper can be downloaded without charge from http://www.ecb.int or from the Social Science Research Network electronic library at http://ssrn.com/abstract_id=891017

I Fatás is Professor of Economics, INSEAD, and CEPR Research Fellow. Mihov is Associate Professor of Economics, INSEAD and CEPR Research Fellow. Rose is Rocca Professor of International Business, NBER Research Associate and CEPR Research Fellow. Rose thanks INSEAD, the Reserve Bank of Australia, and the Monetary Authority of Singapore for hospitality while this paper was written. For comments and suggestions, we thank: Roel Beetsma, Mick Devereux, Andrew Filardo, Jordi Gali, Massimo Giuliodori, Albert Marcet, Patrick Minford, Assaf Razin, Andrew Scott, Ken West, two anonymous referees and workshop participants at the CEPR, ECB and HKMA.The views expressed in this paper are those of the authors and do not necessarily reflect the views of the European Central Bank. A current version of this paper and the data set are available at Rose's website. 2 INSEAD, Boulevard de Constance, 77305 Fontainebleau, France;Tel: +33 (I) 6072-44I9, e-mail:fatas@econ.insead.edu; www.insead.edul fatas 3 INSEAD, Boulevard de Constance, 77305 Fontainebleau, France;Tel: +33 (I) 6072-4434, e-mail: ilian.mihov@insead.edu; faculty.insead.edu/mihov 


\section{International Research Forum on Monetary Policy: Third Conference}

This paper was presented at the third conference of the International Research Forum on Monetary Policy which took place on May 20-21, 2005 at the ECB. The Forum is sponsored by the European Central Bank, the Board of Governors of the Federal Reserve System, the Center for German and European Studies at Georgetown University and the Center for Financial Studies at Goethe University. Its purpose is to encourage research on monetary policy issues that are relevant from a global perspective. It regularly organises conferences held alternately in the Euro Area and the United States. The conference organisers were Ignazio Angeloni, Matt Canzoneri, Dale Henderson, and Volker Wieland. The conference programme, including papers and discussions, can be found on the ECB's web site (http://www.ecb.int/events/conferences/html/intforum3.en.html)

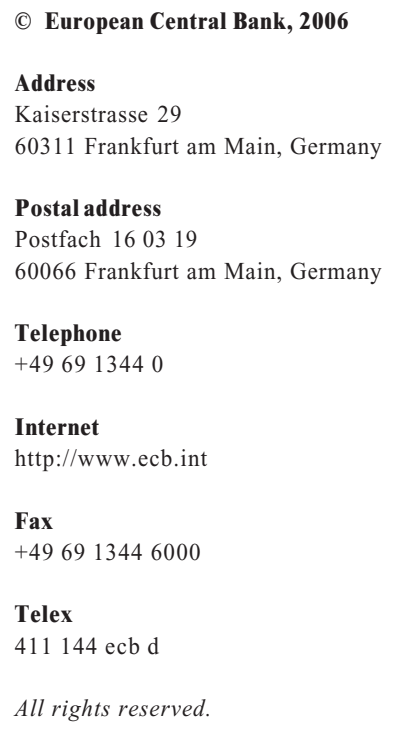

The views expressed in this paper do not necessarily reflect those of the European Central Bank. 


\section{CONTENTS}

Abstract

Non-technical summary

1. Introduction and motivation

2. Literature review 8

3. Methodology 14

3.a Benchmark model

3.b Data description $\quad 17$

4. Empirics 2I

4.a Benchmark results 2 II

4.b Sensitivity analysis 22

4.c Output volatility 28

5. Conclusions 30

References 32

Tables $\quad 35$

Appendices 42

Figures 56

European Central Bank Working Paper Series 


\begin{abstract}
We study empirically the macroeconomic effects of an explicit de jure quantitative goal for monetary policy. Quantitative goals take three forms: exchange rates, money growth rates, and inflation targets. We analyze the effects on inflation of both having a quantitative target, and of hitting a declared target; we also consider effects on output volatility. Our empirical work uses an annual data set covering 42 countries between 1960 and 2000, and takes account of other determinants of inflation (such as fiscal policy, the business cycle, and openness to international trade), and the endogeneity of the monetary policy regime. We find that both having and hitting quantitative targets for monetary policy is systematically and robustly associated with lower inflation. The exact form of the monetary target matters somewhat (especially for the sustainability of the monetary regime), but is less important than having some quantitative target. Successfully achieving a quantitative monetary goal is also associated with less volatile output.
\end{abstract}

Keywords: transparency; exchange; rate; money; growth; inflation; target; business cycle.

JEL Classification Number: E52 


\section{Non-technical summary}

The economics profession has gradually moved to the view that transparency in monetary (and other) policies is desirable. For instance, the IMF believes that transparent policies are both more effective and enhance accountability. But while the theoretical advantages of transparency have been much analyzed, there is less in the way of empirical support. One objective of this paper is to help fill that gap.

We approach this problem empirically by using a panel of annual data covering over forty countries from 1960 through 2000. We identify "transparent" targets for monetary policy with "quantitative" targets. Quantitative targets are easily measured, allowing the monetary authority's successes (or lack thereof) to be determined mechanistically. That is, quantitative targets are transparent since they can be assessed without (much) debatable personal judgment. However, we are not interested in just the effects of having a transparent policy, but also in the effects of successful transparent policy. That is, we are interested in both the de jure monetary regime, and the de facto success of a central bank in hitting its target (if one exists). Using regression analysis, we find that in practice countries with transparent targets for monetary policy achieve lower inflation, holding other things constant. We also find that countries that hit their targets achieve lower inflation.

In practice, central banks have used three types of quantitative monetary targets, with varying degrees of success: exchange rates, money growth rates, and inflation targets. A number of economists in the past have analyzed the effects of one of these regimes. For instance, there is a large and growing literature on countries with inflation targets. There is an even larger literature that compares the merits of fixed and floating exchange rate regimes. Rather than focusing on any one of these targets, we use all three. In part this is because we are interested in 
estimating the effect of transparency in monetary policy, and transparency can take different forms. Indeed, when we compare the effects of different quantitative targets for monetary policy (exchange rate/money growth/inflation) on inflationary outcomes, we find differences, but they are small compared to the presence of any transparent target.

Still, we combine together different types of targets for monetary policy for a more important reason, best explained with an example. Fixed exchange rates are well-defined monetary policies, and are often compared with floating exchange rate regimes. But a float is not a well-defined monetary policy! Similarly, central banks that do not target inflation have to do something else. By using data for all quantitative monetary regimes, we can reasonably compare the merits of having a transparent monetary policy to the alternative, which we consider to be "opaque monetary objective(s)." 


\section{Introduction and Motivation}

The economics profession has gradually moved to the view that transparency in monetary (and other) policies is desirable. For instance, the IMF believes that transparent policies are both more effective and enhance accountability. Accordingly, the Fund encourages countries “... to state clearly the role, responsibility and objectives of the central bank. The objectives of the central bank should be clearly defined, publicly disclosed and written into law." "But while the theoretical advantages of transparency have been much analyzed, there is less in the way of empirical support. One objective of this paper is to help fill that gap.

We approach this problem empirically by using a panel of annual data covering over forty countries from 1960 through 2000. We identify "transparent" targets for monetary policy with "quantitative" targets. Quantitative targets are easily measured, allowing the monetary authority's successes (or lack thereof) to be determined mechanistically. That is, quantitative targets are transparent since they can be assessed without (much) debatable personal judgment. However, we are not interested only in the effects of transparent policy, but in the effects of successful transparent policy; that is we are interested in both the de jure monetary regime, and the de facto success of a central bank in hitting its target (if one exists). Using regression analysis, we find that in practice countries with transparent targets for monetary policy achieve lower inflation, holding other things constant. We also find that countries that hit their targets achieve lower inflation.

In practice, central banks have used three types of quantitative monetary targets (with varying degrees of success): exchange rates, money growth rates, and inflation targets. A number of economists in the past have analyzed the effects of one of these regimes. For instance, there is a large and growing literature on countries with inflation targets. There is an

\footnotetext{
${ }^{1} \mathrm{http}: / /$ www.imf.org/external/np/exr/facts/mtransp.htm
} 
even larger literature that compares the merits of fixed and floating exchange rate regimes. Rather than focusing on any one of these targets, we use all three. In part this is because we are interested in estimating the effect of transparency in monetary policy, and transparency can take different forms. Indeed, when we compare the effects of different quantitative targets for monetary policy (exchange rate/money growth/inflation) on inflationary outcomes, we find differences, but they are small compared to the presence of any transparent target.

Still, we combine together different types of targets for monetary policy for a more important reason, which is best explained with an example. Fixed exchange rates are welldefined monetary policies, and are often compared with floating exchange rate regimes. But a float is not a well-defined monetary policy! Similarly, central banks that do not target inflation have to do something else. By using data for all quantitative monetary regimes, we can reasonably compare the merits of having a transparent monetary policy to the alternative, which we consider to be "opaque monetary objective(s)."

In section 2, we review the extensive literature of relevance; our methodology and data set are presented afterwards. The core of our paper is in section 4, which presents our results for inflation, along with sensitivity analysis. We then analyze the effects of quantitative targets on the short run/business cycle volatility of output. A brief conclusion closes.

\section{Literature Review}

Our work is related to a number of other classic problems in economics. One is the choice of monetary target. Different target have different degrees of transparency (as well as other attributes); accordingly, many scholars have addressed the question of whether central 
banks should use the exchange rate, the money growth rate, the inflation rate, or something else. ${ }^{2}$ Most of this literature is concerned with exchange rate regimes. There is an enormous literature that compares the attributes of fixed and floating exchange rate regimes, both theoretically and empirically. Still, to repeat a standard but important criticism of this area, a fixed exchange rate is a well-defined monetary policy, but a floating exchange rate regime is not. If the monetary authorities are not pegging the exchange rate, they must be doing something else. Because of the recent increase in the adoption of inflation targets, we have seen a shift in the literature towards the study of inflation targeting regimes. Another related literature is that of the optimal degree of transparency in monetary policy. ${ }^{3}$

There is also a literature that has focused on the role of domestic institutions in the conduct of monetary policy, most of which is centred on the effects of independence of central banks, and/or, more recently, on inflation targets. Although these areas of the literature are ultimately addressing the same issue (how monetary policy regimes affect macroeconomic outcomes), it is fair to say that, to a large extent, they have been developed separately. We now review some of the key papers in each of these strands of literature, summarizing their main insights.

\section{Exchange Rate Regimes}

The macroeconomic effect of the exchange rate regime is still an open question, one that is associated with many controversies in both the international and monetary economics literatures. There is a broad literature that deals with the theoretical analysis on the costs and benefits of different exchange rate arrangements and there is a consensus on the main factors that

\footnotetext{
2 See e.g., Atkeson and Kehoe (2001) NBER WP 8681.

3 See e.g., Faust and Svensson (2002), and Cukierman and Meltzer (1986).
} 
shape these costs and benefits. However, there are still many disagreements on the relative empirical importance of these factors. As a result, when it comes to the best monetary policy regime for a given country, most of the predictions are inconclusive as they depend on a variety of assumptions that can only be validated empirically. Relative to the theoretical literature, there have been fewer papers that have taken these assumptions to a test or that, more generally, have empirically estimated the implications of monetary policy regimes.

One of the first papers to provide a comprehensive empirical study of the effects of different exchange rate regimes on macroeconomic outcomes is Baxter and Stockman (1989). Using a cross-section of countries with different exchange rate regime, they looked at the association between the exchange rate regime and variables such as output, consumption, trade flows, government consumption and the real exchange rate. Their conclusion was that the exchange rate regime did not matter for most of the macroeconomic variables, with the exception of the real exchange rate (that was more volatile under flexible exchange rate systems). Flood and Rose (1995) corroborate and extend this finding to other determinants of exchange rates.

Most of the studies that have followed Baxter and Stockman (1989) have had a narrower focus; they look mainly into the consequences on inflation and output volatility. Recent studies by Ghosh et al. (1997, 2002) and Levy-Yeyati and Sturzenegger (2001) provide detailed analyses of the effects of exchange rate regimes on inflation. The approach is to look initially at the marginal effect of the exchange rate regime, after controlling for the effect of money growth. The hypothesis is that the exchange rate regime has a direct effect on the relationship between money and inflation, beyond any potential indirect effect through the conduct of monetary policy (i.e. on money growth rates). There is evidence that inflation is lower under fixed rate regimes. ${ }^{4}$

\footnotetext{
${ }^{4}$ In the case of Levy-Yeyati and Sturzenegger (2003) there is also a test of the indirect effect of the regime on inflation via money growth. Money growth is regressed on GDP growth (lagged), money growth lagged, openness,
} 
Levy-Yeyati and Sturzenegger (2003) and Ghosh et al. (1997) study the effects on business cycle volatility and growth. Regarding business cycle volatility, their results are consistent: fixed exchange rate regimes are associated to greater output volatility. Regarding growth effects, the papers reach different conclusions. While Ghosh et al. (1997) do not find strong evidence in any direction Levy-Yeyati and Sturzenegger (2003) conclude that growth is higher for floaters.

\section{Domestic Institutions}

Even for countries where the discussion on exchange rate regimes is not important (in most cases because of the adoption of floating exchange rates), there has been an active recent debate on optimal monetary policy. The two key issues are typically whether the central bank should have goal-independence, and whether it should have an explicit inflation target.

Regarding the independence of central banks, the literature has focused on the observed negative correlation between inflation and central bank independence as documented in Alesina and Summers (1993), Cukierman (1992) or Grilli et al. (1991).

The other main features of monetary policy that have been studied in this literature are the effects of explicit targets and transparency. Initially the analysis was centred on money targets, but as countries moved away from these targets into inflation ones, the focus of the literature has moved accordingly. Because of the lack of a large number of observations, the literature tends to be descriptive, based on case studies rather than cross-country regressions. Mishkin (1999) and the books by Bernanke, Laubach, Mishkin and Posen (1999) and Loayza and Soto (2002) present good surveys and case studies of money and inflation targeting. Overall the

budget balance, a set of regional dummies and the exchange rate dummies. Once again long pegs are the only cases where there seems to be a significant negative effect on inflation, in this case through lower money growth. 
evidence is mixed. There is evidence that inflation targets have helped countries reduce their inflation rates (Mishkin and Schmidt-Hebbel, 2002). On the other hand, Ball and Sheridan (2005) argue that this effect has been due to factors other than the monetary regime (while assuming that inflation reverts to a low mean).

\section{Regimes}

In all the literature reviewed above, two issues appear repeatedly: the characterization of monetary policy regimes (especially when it comes to exchange rate regimes) and the problem of endogeneity.

Classification of regimes: words or actions? When it comes to the classification of exchange rate regimes, there are two possible approaches. The first is to look at the officially declared de jure regime. The problem with this approach is that we often observe in practice that countries sometimes peg their exchange rate without a clear de jure commitment (or intervene frequently despite having declared a floating exchange rate, the "fear of floating" as defined by Calvo and Reinhart, 2000). As an alternative one can look at actions and classify regimes but looking at the actual behaviour of exchange rates (or the target set by monetary policy), i.e., the de facto regime. This is the approach of Reinhart and Rogoff (2004) and Levy Yeyati and Sturzenegger $(2001,2003)$. Their results show that looking at a de facto classification might provide very different results. The distinction between words and actions also matters for other monetary policy targets such as money and inflation targets. For example, there is plenty of evidence that central banks that declared themselves to be money targetters were not behaving as such (see, for example, Bernanke and Mihov (1997) for the case of the Bundesbank). 
Rather than attempt to resolve this issue on a conceptual level, we look at both the effects of having a transparent de jure monetary regime, and whether or not it is hit de facto in practice.

Dealing with endogeneity. The interpretation of the existence of a correlation between inflation (or output volatility) and the exchange rate regime is problematic because of endogeneity. Is inflation lower because of the fixed exchange rate regime? Or are countries with low inflation (or more distaste of inflation) more likely to adopt fixed exchange rate regimes? The literature has dealt with the issue of endogeneity by using a set of instrumental variables based on either economic or political arguments. ${ }^{5}$ Levy-Yeyati, Sturzenegger and Reggio (2002) or von Hagen and Jizhong Zhou (2004) provide a comprehensive study of the endogeneity of exchange rate regimes. Frieden, Ghezzi and Stein (2000), within the context of Latin America, use a similar framework. Alesina and Wagner (2003) provide an analysis of how institutions affect decisions by countries to abandon fixed exchange rate regimes and to dissemble why such regimes are in place.

The arguments about what determines the choice of an exchange rate regime are based on theories that highlight the economic costs and benefits of the regimes, as well as the political institutional environment in which different regimes might be preferable. The economic variables are related to the optimum currency area debate. What makes a country a better candidate to adopt the currency of a different country? Openness, size, geographical concentration of country's trade, the type of shocks (volatility of terms of trade, volatility of other nominal versus real shocks), financial dollarization all matter to assess these costs and benefits and have been used as instrumental variables in the literature.

\footnotetext{
${ }^{5}$ A separate but related issue is the need to control for variables other than the monetary policy regime in the determination of inflation. Romer (1993) or Lane (1997) are examples of papers that have studied how the determinants of the incentives of governments to inflate their economies.
} 
The political arguments are more institutional, and concern the benefits of committing to a certain monetary policy. From a theoretical point of view, fragmentation of power (measured by e.g., the fraction of seats in congress held by government, years in office, or a Herfindahl index of political parties) or political instability shape the benefits and costs of commitment when it comes to monetary policy or the exchange rate regime. There is evidence that these variables matter (Frieden, Ghezzi and Stein (2000) or Edwards (1996)).

The issue of endogeneity has rarely been studied in the case of money or inflation targets. One of the few exceptions is Gerlach (1999) in the context of inflation targets. His results show that the adoption of inflation targets is more likely with low degree of central bank independence, less openness, countries that export a low number of goods and among members of the EU.

\section{Methodology}

Our question is whether the establishment of a quantitative target for monetary policy matters for inflation, ceteris paribus, and also whether hitting a target (if it exists) matters. We can think of two ways to proceed. First, we could pursue case studies, as is done in much of the literature. This has a number of advantages. Precise details concerning monetary institutions, policy, and other factors can be used. The underlying economy changes little, so one can focus on monetary policy. It is difficult to measure monetary regimes perfectly; for instance some countries began dis-inflation programs without a contemporaneous switch in monetary regime (New Zealand in the late 1980s and Sweden in the mid 1990s come to mind). Still, the case study approach has a big disadvantage: one does not end up with estimates that are general. Accordingly, in this paper we seek to extend the literature by pursuing an econometric approach 
that spans both long periods of time and a number of countries. The advantage of our approach is its generality, but it may come at the cost of precision. In particular, we are forced to restrict ourselves to variables that can be measured similarly for a large number of observations; we highlight these issues below.

\section{3.a Benchmark model}

Our benchmark model is the following:

$$
\begin{aligned}
\Pi_{\text {it }} & =\beta_{1} \text { DJTarget }_{\text {it }}+\beta_{2} \text { Success }_{\text {it }} \\
& +\gamma_{1} \text { Open }_{\text {it }}+\gamma_{2} \text { Budget }_{\text {it }}+\gamma_{3} \text { BusCycle }_{i t}+\gamma_{4} \text { GDPpc }_{i t}+\gamma_{5} \text { GDP }_{i t}+\varepsilon_{i t}
\end{aligned}
$$

where i denotes a country, $t$ denotes a year, and

- $\Pi$ denotes the annual inflation rate in percentage points

- DJTarget ${ }_{\mathrm{t}}$ is a dummy variable that is one if the country had a quantitative monetary policy target during period $t$, and zero otherwise,

- $\gamma_{\mathrm{i}}$ is a set of nuisance coefficients,

- Success is a dummy variable that is one if the country hit its de jure quantitative target during t, and zero otherwise,

- Open is trade (exports plus imports) as a percentage of GDP,

- Budget is the government budget surplus (+) or deficit (-), as a percentage of GDP,

- BusCycle is the difference between real GDP growth and average (country-specific) GDP growth, measured in percentage points,

- GDPpc is the natural logarithm of real GDP per capita,

- GDP is the natural logarithm of real GDP, and

- $\varepsilon$ is a well-behaved residual term for all other inflation determinants. 
The two coefficients of interest to us are $\beta_{1}$ and $\beta_{2}$. The first coefficient is of greatest interest; it represents the effect of having a formally declared de jure quantitative monetary target on inflation, ceteris paribus. Also of interest to us is $\beta_{2}$, which shows the effect on inflation of successfully hitting a quantitative monetary target (if one exists) de facto.

The other regressors control for "nuisance" factors that affect inflation and might be correlated with the monetary policy regime, but are not of direct interest to us. Romer (1993) argues that more open economies have lower inflation because the costs of monetary expansion are high when the country has high trade-to-GDP ratio. More open economies might also opt for a fixed exchange rate relative to their trading partners as argued by the literature on the optimal currency areas. This argument prompts us to include Open as a regressor. The budget balance (Budget) can affect inflation by imposing requirements for money-financed deficits or through aggregate demand. At the same time the success in hitting a monetary target can be affected by fiscal policy outcomes. We also include the state of the business cycle (BusCycle) as a measure of aggregate demand pressures on the price level and as a covariate that might be correlated with the success of the monetary regime. GDP per capita (GDPpc) enters the regression to account for the fact that rich countries have more sophisticated financial sectors, which implies higher opposition to inflation (as in Posen, 1995) and lower optimal inflation tax because of betterdeveloped standard tax instruments. Posen's argument also suggests that rich countries have low incentives to adopt an explicit target given that there is already pressure to achieve low inflation. Finally, the level of GDP is included to account for the market size. Since market size can affect productivity as in the models of Romer (1986) or Lucas (1988), a larger country may have lower inflation ceteris paribus. On the correlation between country size and explicit targets, one might argue that larger countries are less likely to adopt an exchange rate target. 
Our benchmark regression is similar to those used by Levi-Yeyati and Sturzenegger (2001), and Ghosh et al. (2002). The theoretical motivation for their econometric specification is quite similar to ours, except that these studies focus only on the exchange rate regime. Campillo and Miron (1996) provide also a cross-sectional investigation of determinants of inflation and the regressors are almost identical to the ones we use, but they do not include any variable that captures the nature of the monetary regime.

We estimate the model with least squares, and use robust standard errors. Still, we are cognizant of a number of potential econometric pitfalls associated with this strategy (e.g., simultaneity). Accordingly, we do perform extensive sensitivity analysis to take into account a variety of different issues.

\section{3.b Data Description}

A data appendix describes in detail the sources and the list of variables used in our empirical analysis. Our annual data set spans 1960 through 2000, and includes all countries with 1960 GDP per capita of at least $\$ 1000$ dollars in the Penn World Table database for which comprehensive data are available. There is significant variation in monetary policy practices both over time and across countries in the data set. Exchange rate pegs are more common in the 1960s, money targets disappear from many countries during the 1980s, inflation targeting only appears in the 90s. For most of our analysis we use annual frequency (given that we are not interested in high-frequency properties of the data), but we provide sensitivity analysis by replicating our results using five-year averages.

We use two variables to characterize the monetary policy regime: whether or not there was an announced de jure target and whether or not the target was hit de facto. Our approach is 
complementary to that of the previous literature. As mentioned in our literature review, previous papers have struggled with the issue of "words versus actions". Central banks often claim to have adopted strict monetary policy targets, whether they are monetary aggregates, exchange rates, or inflation targets. In many cases these claims are not validated by their actions or the data. Some obvious examples of this behavior include: countries that intervene on foreign exchange markets extensively despite having a floating exchange rate policy; missed targets for monetary aggregates; and missed inflation targets. Our strategy is to capture with our de jure classification of monetary regimes the stated announcements of central banks, and then also to look separately at whether or not the target was hit in practice.

Establishing a de jure classification for exchange rate and inflation targets is not conceptually complicated, though there is much debatable minutiae. In the case of targets for monetary aggregates, there are several cases where a judgment call needs to be made; many central banks use monetary aggregates as reference indicators for their monetary policy without formally targeting money growth. We try not to take this logic too far, because we are interested in words (not actions) for our de jure classification. For example, the Bundesbank is classified as having a target for money even though we know that in practice the commitment to the target was weaker than the Buba's words.

There is one complication that we have to address before we proceed with the estimation of our benchmark model. Sometimes countries change their monetary regimes in mid-year. This presents a potential problem for our estimation because for the year when there is a change we will use data for the dependent variable and the controls that correspond to two regimes at the same time. Had we known the exact date of the regime change, we could remove that year. 
Unfortunately we do not have this information for a good number of observations. ${ }^{6}$ Accordingly, we delete adjacent years with different regimes, so that each regime shift entails two dropped observations. The impact of a switch in monetary regime may be pronounced in the year when it takes effect, especially for countries that are engaged in a dis-inflation campaign, so this may dilute our estimates. ${ }^{7}$ We feel most comfortable proceeding conservatively, and cannot see any bias associated introduced by this convention.

Our de facto classification of monetary policy regimes provides a measure of whether or not the announced targets were met. For simplicity, we classify monetary authorities as either hitting or missing their targets; that is we use a binary $0 / 1$ variable to indicate success or failure of the monetary authorities in achieving their target. Future work might consider finer or continuous gradations of success, since central banks often have partial success in hitting monetary targets. ${ }^{8}$

In the case of the exchange rate targets we make use of the Reinhart and Rogoff classification that characterizes exchange rate regimes by their actions (not their words). This has the advantage of covering a broad array of countries, and was not created by us (so that it is objective). ${ }^{9}$ In the case of inflation and money targets we simply compare the outcome (inflation or money growth) with the announced range for the target. Still, we face several difficulties in making this comparison. First, targets are sometimes expressed as a single number, while for

\footnotetext{
${ }^{6}$ When we know the date of a regime shift, we follow the convention of dating it to the year when it was first in place for at least six months.

7 For instance, when Canada introduced money growth targeting in 1976, its inflation fell from 10.8\% the year before to $7.5 \%$. A more extreme example is the introduction of the Argentine convertibility; when it was introduced in 1991 , inflation fell from over $2000 \%$ to around $170 \%$.

${ }^{8}$ It would be natural to pursue this angle through a loss function approach, though there could be problems if the monetary target is a range rather than a point.

9 Reinhart and Rogoff treat realignments from one fixed exchange rate to another as falling within a fixed exchange rate regime. This is debatable; on the one hand, the central bank has not achieved its monetary target, while on the other hand the monetary regime remains intact "in the large." We return to this issue below when we consider IV estimation.
} 
others a range is provided. When an explicit range is provided we simply assess whether or not the outcome is within the range. If there is no band around the announced target, we either consider the target as a maximum (by establishing a range from 0 to the announced value) or we build a range around the target. We consider the value as a maximum when the central bank is clearly trying to bring inflation down and establishes a series of decreasing targets for the years ahead. We add a range to the target when this is consistent with previous or future behavior of that central bank. For example, there are also instances where central banks switch from an explicit range to a single point. In those cases we add a band of around the announced target of the same size as the band that was in place in previous years. ${ }^{10}$

The second difficulty associated with determining whether or not a target was hit is measuring the outcome. Money and inflation targets are established for a specific measure of inflation or a monetary aggregate. In some cases, the information about the precise measure being used is unavailable. In others, we know the variable used, but have not been able to find the data. As a result, we are missing some observations. In the case of inflation, we use the CPI as our measure of the price index. In the case of monetary aggregates, we normally use information on both target and outcome that originate from the same source. ${ }^{11}$

The appendix also provides two figures with a comprehensive set of simple country-bycountry time series plots of inflation; different monetary regimes are marked by different symbols. During this period of time, lower inflation was typically better inflation, though not for all countries and period of time (e.g., Japan during the 1990s which probably experienced

\footnotetext{
${ }^{10}$ In the very few cases where we cannot find information or a historical reference to establish a band, we use the convention of adding one percentage point to each side of the target. Details are provided in the data appendix.

${ }^{11}$ If this is not the case and the information on the specific monetary target being used is not available, then we leave the observation as missing.
} 
excessively low inflation). Thus our methodology does not deliver a message about welfare, and it would be inappropriate for a sample where inflation was typically low.

Perhaps a more effective way to present the data graphically is through an "event study." Figure 3 is a set of event studies that look at inflation around the dates of changes in monetary regime. The top left-hand diagram examines inflation in the three years before, during (marked by the vertical line), and after entry; it considers entry into de jure regimes of any sort. The middle line (with circles) shows the mean level of inflation, while the two other lines show a confidence interval of plus and minus two standard deviations. The diagram in the top righthand corner is the analogue showing exits from de jure regimes, while the diagrams below are analogues that exclude the high-inflation countries. While none of the event studies is overwhelmingly persuasive, each of them provides a message consistent with the results we verify more rigorously below. In particular, the entry intro a monetary regime with a quantitative target coincides with a reduction in inflation, while exits from such regimes are associated with increases.

\section{Empirics}

\section{4.a Benchmark Results}

OLS estimation of our model results in the benchmark estimates presented in Table 1. The coefficient of greatest interest to us is $\beta_{1}$, the effect on inflation of a country's having a quantitative target for monetary policy of any type (whether an inflation target, a money growth target, or an exchange rate target). The effect is both economically and statistically significant; the existence of a de jure target is estimated to lower annual inflation by about sixteen percentage points, with a t-statistic greater than five in absolute value (and hence different from 
zero at all conventional significance levels). This effect is enhanced if the quantitative target is actually hit. A monetary target that is successfully achieved reduces inflation by another five percentage points, a result that is again highly statistically and economically significant.

Our basic framework is perturbed in three ways in Table 1. First, we drop the dummy variable for successful implementation of a quantitative monetary target. Second and symmetrically, we also drop the dummy representing the existence of a quantitative target. Each of the coefficients remains economically and statistically significant if the other is set to zero. Finally, we drop all the conditioning variables (that is, we set $\gamma_{1}=\gamma_{2}=\ldots=\gamma_{5}=0$ ).

At first blush it seems that countries with transparent (quantitative) de jure monetary targets experience lower inflation. Actually hitting the target lowers inflation further. While the preliminary findings are positive, caveats certainly exist. For one thing, the model fits the data poorly. While many of the auxiliary regressors are correctly signed (more open economies have lower inflation; tight fiscal policy lowers inflation; richer economies have lower inflation), some are not (observations with higher-than-average growth display lower inflation). Furthermore, a number of potentially important omitted variables and econometric complications come to mind quickly. Accordingly, we now engage in sensitivity analysis.

\section{4.b Sensitivity Analysis}

Table 2 checks the sensitivity of the results with respect to the precise sample used for estimation. First we drop observations before 1975. Next we drop all observations where the (country $\mathrm{x}$ year) observation is for a country with real GDP per capita below $\$ 5,000$. Another perturbation restricts our attention to long-time OECD members (those that entered before 1975). 
Next we drop outlier observations. ${ }^{12}$ Our last two changes are to add in Argentina and Brazil, two high inflation countries, and then to drop all high inflation countries, defined as a country which experienced inflation exceeding $100 \%$ annually at any point in our sample (Chile, Israel, Mexico, Turkey and Uruguay). It is striking that our key coefficient of interest $-\beta_{1}-$ remains economically large and statistically significant in all of these perturbations. (The size of the effect of course varies with the sample; excluding high-inflation countries reduces considerably the potential and actual influence of a quantitative monetary target.) Further, $\beta_{2}$ is also significantly negative (in both the economic and statistical senses) in all cases except when Argentina and Brazil are included in the sample. ${ }^{13}$

Do our results depend on regime switches associated with major oil price shocks? No. In an appendix we tabulate the analogues to Tables 1 and 2, computed only with data after 1982. These show quite similar results to our benchmark results. Appendix Table A6 tabulates estimates of the key coefficients computed from the four different decades of data. Again, our key coefficients remain negative (and mostly significant at standard confidence levels) with the exception of the 1960 s de jure coefficient, which is insignificantly positive. It seems that restricting ourselves to data after the second OPEC oil price shock does not change our results substantively. ${ }^{14}$

In Table 3 we check the robustness of our results with respect to unobserved country- and time-specific factors. We do this by adding successively: a) country-specific intercepts, b) yearspecific intercepts, and c) country- and year-specific intercepts simultaneously. Using country-

\footnotetext{
12 The latter are defined as observations with a residual estimated to lie more than 1.5 standard deviations from the mean of zero.

${ }^{13}$ We have also dropped the countries with maximal inflation exceeding $38.2 \%$ (which corresponds to the $75^{\text {th }}$ percentile of our sample), and countries with average inflation exceeding $13 \%$ (which again corresponds to the $75^{\text {th }}$ percentile of our sample). In both cases, the coefficients on both de jure quantitative regimes and the success in hitting the target remain negative, though only the latter coefficients are significantly different from zero.

${ }^{14} \mathrm{We}$ also note that there is a poor overlap between departures from quantitative monetary regimes and major oil price changes.
} 
specific fixed effects is an important check, since it means that the estimation relies only on within-country variation in inflation and monetary regimes over time. Using year-specific fixed effects because it accounts for any global factors such as oil prices global inflation and the global business cycle. Another column of the table adds dynamics to the perturbation with both sets of fixed effects by modeling the error term as an $\mathrm{AR}(1)$ disturbance rather than serially uncorrelated. Finally, we use the one-year lead of inflation in the last column on the right, since inflation responds to policy with a lag. ${ }^{15}$ Again, our key coefficient remains negative and significant throughout (though adding country effects eliminates the significance of the effect of achieving a monetary target).

Table 4 explores whether the three types of quantitative monetary policy targets inflation, money growth, and exchange rate - have similar effects on inflation. When the three different regimes are allowed to take on different coefficients, the inflation-targeting regime seems to have more of a dampening effect on inflation than the (similar) effects of either exchange rate or money growth targets. The differences between the three targets are significant at conventional confidence levels. The effect of a successfully hit monetary target on inflation also varies by the type of target; surprisingly, the effect of successfully hitting an inflation target has a positive coefficient. ${ }^{16}$ Still, the most important differences between different types of monetary regimes may be not in their outcomes, but their sustainability. Many countries have abandoned both exchange rate and money growth targets; none has (yet) abandoned an inflation target. Our analysis does not capture these differences, and this would be an interesting area for future research.

\footnotetext{
${ }^{15}$ Using a lead of inflation also helps to reduce problems with endogeneity; more on that below.

${ }^{16}$ A closer inspection of the data reveals that several countries have indeed missed the target by having inflation below the target range. For example, Sweden in the 1990s had a range between 1\% and 3\% inflation, but in four years inflation was below $1 \%$. This result is fragile though; the coefficient becomes negative if country-specific fixed effects are added.
} 
Table 5 shows that the effects of political instability on inflation are of negligible importance using revolutions and coups (the variables used by Campillo and Miron, 1996). While coups are associated with a drop in inflation, our key coefficients are little affected.

Table 6 uses instrumental variables estimation to account for possible simultaneity in the equation. ${ }^{17}$ We are particularly concerned with the possibility that high inflation induces the authorities to introduce or use quantitative targets. There is also the possibility that a low inflation environment may encourage the authorities to lock in stability with a transparent monetary policy.

As instrumental variables for both our de jure monetary dummy, and the dummy variable for de facto success in hitting this target, we use three political variables and two variables capturing social characteristics. They are: a) political constraints (used by Henisz, (2000)); b) a dummy for (country x year) observations with a presidential electoral system (taken from Persson-Tabellini, 2001); c) a comparable dummy for observations with majoritarian electoral systems (again taken from Persson-Tabellini, 2001); d) the percentage of males over 25 years old with completed primary education; and e) the percentage of males over 25 years with completed secondary education. We use these variables for a number of reasons. The presence of political constraints in the country reveals an overall preference for rules. In addition, countries with more political constraints have more disciplined fiscal policy. With more discipline on the fiscal side it is more likely that that a monetary regime is sustainable. A somewhat different argument is that if political constraints restrict fiscal policy, then society might prefer to leave monetary policy unconstrained and assign to it a bigger role in smoothing business cycle fluctuations. The nature of the political system (presidential vs. parliamentary) affects regime choice in a similar

\footnotetext{
${ }^{17}$ Measurement error is also a potential issue, especially for de jure monetary performance; as we note above, there may be issues associated especially with exchange rate realignments.
} 
way. Presidential regimes are often characterized by better separation of powers than parliamentary ones, because the president cannot be subjected to a no-confidence vote by the parliament (except under rare circumstances of impeachment). The executive in a parliamentary system, on the other hand, can be more easily removed. The separation of powers in a presidential system again makes fiscal policy rather constrained, which boosts the case for having flexible monetary policy. The electoral system matters because countries with majoritarian systems are associated with stronger governments relative to those with proportional representation. Proportional systems often lead to the need for coalitions to form a government; Levy-Yeyati, Sturzenegger and Reggio (2002) argue coalition governments are more prone to be influenced by special interests. To avoid a situation where special interests affect monetary policy, the society might opt for a regime with an explicit target. Hence majoritarian systems should be linked with a more flexible regime. Finally the two education variables are used since more educated societies may insist on having institutions for low inflation, while education has no direct effect on inflation.

We provide four different perturbations of our IV results: benchmark; with country-fixed effects; with year intercepts; and with both. The standard errors for the coefficients of interest are considerably higher, indicating that the first-stage regressions do not fit well. That is, our instrumental variables do not work particularly well. This is even more obvious from the dramatic increase in the size of the effects; the IV estimates of $\beta_{1}$ are approximately three times the magnitude of the OLS estimates. Once we control for unobserved country fixed effects, the coefficient on monetary success in hitting a quantitative target becomes positive and significant. It is difficult to provide a reasonable interpretation of this reversal. The effect of de jure regime on inflation is, however, consistently negative and highly significant. The final four columns add 
as instrumental variables the lags of the de jure regime and de facto monetary success. ${ }^{18}$ These instruments help with addressing issues of omitted variables (e.g. a beneficial supply shock that leads to lower inflation and also helps the central bank hit the target). The results are highly significant and consistent with the findings of our benchmark model.

Our final set of experiments moves away from the annual domain to consider data averaged over mutually exclusive and jointly exhaustive five-year intervals between 1960 and 1999 (1960-64, 1965-69, and so forth). These are contained in Table 7, which tabulates our key coefficients estimated twelve different ways. For convenience, the auxiliary regressors (openness, the budget, and so forth) are included in the regressions but not explicitly tabulated. The benchmark equation is presented in the top row. The other eleven perturbations we consider include: a) dropping observations before 1975 ; b) dropping all (time period $\mathrm{x}$ country) observations with real GDP per capita below $\$ 5,000$; c) dropping all controls (i.e., setting $\gamma_{1}=\gamma_{2}=\ldots=\gamma_{5}=0$ ); d) adding Argentina and Brazil; e) dropping our five high inflation countries (Chile, Israel, Mexico, Turkey and Uruguay); f) adding country intercepts; g) adding time-period effects; h) adding both country- and time-period fixed effects; i) adding an AR(1) residual to the country- and time-period intercepts; j) using IV on the benchmark equation; and k) using IV with country and time-period intercepts. Our key coefficient, $\beta_{1}$, remains negative, economically large and statistically significant except when we exclude our high inflation countries and when we estimate the model by IV with time and country effects. Also when we include AR(1) errors into panel estimation the significance drops to about $10 \%$ level. This is ground for some caution, but not perhaps too much. Smoothing the data and excluding countries that have ever

\footnotetext{
18 This effectively deals with supply shocks that affect both inflation and the probability of de facto monetary success (since the lag of the de jure regime is collinear with the contemporaneous value).
} 
experienced high inflation may simply reduce the variation in inflation too much to allow the effects of a quantitative target to be detectable. ${ }^{19}$

\section{4.c Output Volatility}

We now briefly present results on output volatility, which we investigate for two reasons. Many central banks (such as "flexible" inflation-targeters) care about stabilizing the output gap. We are also interested to see if the effects of transparent monetary regimes that we uncovered above come at the expense of increased output volatility.

Our benchmark model for the volatility regression is analogous to that for inflation:

$$
\sigma_{i t}=\beta_{1} \text { DJTarget }_{i t}+\beta_{2} \text { Success }_{i t}+\gamma_{1} \text { Open }_{\text {it }}+\gamma_{2} \text { Budget }_{i t}+\gamma_{3} \text { GDPpc }_{i t}+\gamma_{4} \text { GDP }_{\text {it }}+\varepsilon_{i t}
$$

where i denotes a country, $t$ denotes a 5 -year period, and

- $\sigma$ denotes output volatility (defined carefully below), and

- other variables are as defined above.

For output volatility, we initially use the five-year average absolute deviation of output growth from mean growth (calculated from annual data). That is, we first compute the countryspecific mean growth rate using the entire span of annual data, which we denote as $\overline{\Delta G D P_{i}} \equiv(1 / T) \Sigma_{t} \Delta G D P_{i t}$, then compute our regressand as $\sigma_{i t} \equiv(1 / 5) \Sigma_{\tau}\left|\Delta G D P_{i t}-\overline{\Delta G D P_{i}}\right|$ for non-overlapping, mutually exclusive five-year periods, where GDP denotes the natural logarithm of GDP. ${ }^{20}$

\footnotetext{
${ }^{19}$ We have also searched without success for an effect of quantitative regimes on inflation volatility. Our results are in an appendix, and are likely the result of the well-known correlation between the level and volatility of inflation. ${ }^{20}$ We would prefer to use the volatility of the "output gap"; that is (the volatility of) deviations of output from that which would prevail if all prices were flexible. Constructing the output gap for a wide array of countries is beyond
} 
We start directly with five-year averages in order to provide a better estimate of business cycle volatility. The coefficients of interest again are $\beta_{1}$ and $\beta_{2}$. The benchmark results for the volatility equation are reported in Table 8 . From the first column we conclude, that the coefficients on both de jure and de facto regimes are not statistically significant at the $5 \%$ level of significance. This implies that having an explicit target does not affect output volatility - that is, average absolute deviation of output growth from its mean. If the target is successfully achieved, however, then the volatility is reduced by about half of a percentage point. This result should not be over-interpreted as it is significant only at the $10 \%$ level.

The rest of Table 8 reports several sensitivity checks. In column 2 we drop the dummy for "Success in achieving the target" and in column 3 we drop the de jure variable. In both cases the estimates of the regime remain insignificant. Adding a lag of our volatility measure does not change the main conclusion that explicit targets do not affect significantly volatility of output.

In Table 9 we explore the sensitivity of these results in several dimensions. We start by including Argentina and Brazil in column (1) and by removing all of the high inflators in column (2). Again, hitting the target has a negative effect on volatility but statistically this result is significant at the $10 \%$ level at best. Adding unobserved time effects increases the significance of the success variable, but overall we find that there is little evidence to support any claim on the effect of policy regimes on output volatility.

Table 10 dis-aggregates the effects of monetary regimes on output volatility into those due to inflation, money growth, and exchange rate targets. There are no significant results that one can interpret here. Table 11 pursues instrumental variable estimation so as to account for endogeneity. When we use our political and education variables as instrumental variables, and 
also when we add lagged regimes, the effects of de jure and de facto regimes remain statistically insignificant, which could be again a signal that these are poor instruments or that volatility is indeed unrelated to the monetary policy regime. Finally, in Table 12 we provide analogues to OLS and IV estimation of our default model, but measuring output volatility in three different ways: a) the average absolute value of the deviation of real GDP from HP-filtered real GDP (in $\operatorname{logs}), b)$ the average absolute value of deviation of output growth from a ten-year average growth rate, or c) the standard deviation of output growth computed over (mutually exclusive) decades of annual data. ${ }^{21}$ The estimates of having a de jure quantitative monetary target are insignificant, but the estimates for successfully hitting this target are typically but not overwhelmingly statistically significant.

The conclusion from the volatility regressions is that, at a minimum, having an explicit monetary target does not increase the volatility of the economy. On the contrary, our evidence suggests that the coefficients on successfully hitting a target are negatively and significantly (in the economic sense) associated with lower volatility. Under several perturbations of our model these coefficients are statistically significant at the $10 \%$ level.

\section{Conclusions}

In this paper we investigate the effect of quantitative targets for monetary policy on inflation and business cycle volatility. We combine data for three types of targets for monetary policy (exchange rate targets, money growth targets, and inflation targets), so as to be able to compare the effects of both having and hitting transparent objectives for monetary policy against the alternative of having unclear or qualitative goals. Using a panel of macroeconomic data covering over forty years of annual data and countries, we find that having a quantitative de jure

\footnotetext{
${ }^{21}$ We use a smoothing parameter of $\lambda=100$.
} 
target for the monetary authority tends to lower inflation and smooth business cycles; hitting that target de facto has further positive effects. These effects are economically large, typically statistically significant and reasonably insensitive to perturbations in our econometric methodology. Differences in the exact form of the monetary regime have more minor effects on actual inflation than having some quantitative target, though some monetary regimes seem more easily sustainable than others.

During the past decade, there has been much emphasis placed on the importance of transparent goals for monetary authorities; the current consensus is that central banks should independently pursue well-defined goals in a transparent fashion. Our results lead us to conclude that this emphasis seems justified. 
References:

Agenor, Pierre-Richard (2002), "Monetary Policy under Flexible Exchange Rates: An Introduction to Inflation Targeting", in Norman Loayza and Raimundo Soto (eds.) Inflation Targeting: Design, Performance, Challenges, Central Bank of Chile.

Alesina, Alberto and Lawrence Summers (1993), "Central Bank Independence and Macroeconomic Performance: Some Comparative Evidence," Journal of Money, Credit and Banking, 25:151- 62 .

Alesina, Alberto and Alexander Wagner (2003), "Choosing and Reneging on Exchange Rate Regimes,” Harvard Institute of Economic Research Discussion paper no. 2008.

Atkeson, Andrew and Patrick J. Kehoe (2001), "The Advantage of Transparent Instruments of Monetary Policy,” NBER Working Paper no. 8681, December.

Ball, Laurence and Niamh Sheridan (2005), "Does Inflation Targeting Matter?" in Ben Bernanke and Michael Woodford (eds.) The Inflation-Targeting Debate, Chicago, University Press.

Baxter, Marianne and Alan Stockman (1989), "Business Cycles and the Exchange Rate System: Some International Evidence," Journal of Monetary Economics 23, 377-400.

Bernanke, Ben, Thomas Laubach, Frederic Mishkin and Adam Posen (1999), Inflation Targeting. Princeton, NJ: Princeton University Press.

Bernanke, Ben and Ilian Mihov (1997), "What Does the Bundesbank Target?” European Economic Review 41.

Calvo, Guillermo and Carmen Reinhart (2002), "Fear of Floating," Quarterly Journal of Economics 117, 379-408.

Campillo, Marta and Jeffrey Miron (1997), "Why Does Inflation Differ Across Countries?" in C. Romer and D. Romer (eds.) Reducing Inflation: Motivation and Strategy, Chicago: University of Chicago Press.

Cottarelli, Carlo and Curzio Giannini (1997), "Credibility Without Rules? Monetary Frameworks in the Post-Breton Woods Era”, IMF Occasional Paper No. 154.

Cukierman, Alex and Allan Meltzer (1986), "A Theory of Ambiguity, Credibility, and Inflation under Discretion and Asymmetric Information,” Econometrica 54, 1099-1128.

Cukierman, Alex (1992), Central Bank Strategy, Credibility and Independence: Theory and Evidence. MIT Press, Cambridge. 
Edwards, Sebastian (1996), "The Determinants of the Choice Between Fixed and Flexible Exchange Rate Regimes,” NBER Working Paper No. 5756.

Faust, Jon and Lars Svensson (2002), "The Equilibrium Degree of Transparency and Control in Monetary Policy," Journal Of Money Credit And Banking, May.

Flood, Robert P. and Andrew K. Rose (1995) "Fixing Exchange Rates: A Virtual Quest for Fundamentals" The Journal of Monetary Economics 36-1, 3-37.

Frankel, Jeffrey and David Romer (1999) "Does Trade Cause Growth?” American Economic Review, vol. 89 June.

Frieden, Jeffry, Piero Ghezzi and Ernesto Stein (2000), "Politics and Exchange Rates: A CrossCountry Approach to Latin America," Inter-American Development Bank Working paper no. R421.

Gerlach, Stephen (1999), “Who Targets Inflation Explicitly?” European Economic Review 43, $1257-1277$.

Ghosh, Atish, Anne-Marie Gulde, Jonathan Ostry, and Holger Wolf (1997), "Does the Nominal Exchange Rate Regime Matter,” NBER Working Paper no. 5874.

Ghosh, Atish, Anne-Marie Gulde, and Holger Wolf (2002), Exchange Rate Regimes, Cambridge, MA: MIT Press.

Grilli, Vittorio, Donato Masciandaro and Guido Tabellini (1991), "Political and Monetary Institutions and Public Financial Policies in the Industrial Countries", Economic Policy, 341-302.

Henisz, Witold J. (2000), “The Institutional Environment for Economic Growth,” Economics and Politics 12(1).

Lane Philip. (1997) 'Inflation in Open Economies," Journal of International Economics, 42, May 1997, No.3/4, 327-346.

Levi-Yeyati, Eduardo and Federico Sturzenegger (2001), "Exchange Rate Regimes and Economic Performance" IMF Staff Papers 47, 62-98..

Levi-Yeyati, Eduardo and Federico Sturzenegger (2003), "To Float or to Fix: Evidence on the Impact of Exchange Rate Regimes on Growth", American Economic Review 93(4).

Levi-Yeyati, Eduardo, Federico Sturzenegger, and Reggio (2002), "On the Endogeneity of Exchange Rate Regimes," manuscript.

Loyaza and Soto (2002) (eds.), Inflation Targeting: Design, Performance, Challenges, Central Bank of Chile. 
Lucas, Robert (1988), "On the Mechanics of Economic Development," Journal of Monetary Economics 22, 3-42.

Mishkin, Frederic S. (1999), "International Experiences with Different Monetary Policy Regimes," NBER Working Paper No. 7044.

Mishkin, Frederic S. and Schmidt-Hebbel Klaus (2003), "A decade of Inflation Targeting in the World: What Do We Know and What Do We Need to Know? in Norman Loayza and Raimundo Soto (eds.) Inflation Targeting: Design, Performance, Challenges, Central Bank of Chile.

Persson, Torsten and Guido Tabellini (2001), "Political Institutions and Policy Outcomes: What are the Stylized Facts?” CEPR Discussion Paper No 2872.

Posen, Adam (1995), "Declarations Are Not Enough: Financial Sector Sources of Central Bank Independence," in B. Bernanke and J. Rotemberg (eds.), NBER Macroeconomics Annual 10, Cambridge, MA: MIT Press, 253-274.

Reinhart, Carmen and Kenneth Rogoff (2004), "A Modern History of Exchange Rate Arrangements: A Reinterpretation," Quarterly Journal of Economics 119(1), pp. 1-48.

Romer, David (1993), "Openness and Inflation: Theory and Evidence," Quarterly Journal of Economics 108, 869-903.

Romer, Paul (1986), "Increasing Returns and Long Run Growth," Journal of Political Economy 94, pp.1002-37

Siklos, Pierre L. (1999), "Inflation-Target Design: Changing Inflation Performance and Persistence in Industrial Countries", Federal Reserve Bank of St. Louis Review, March/April.

Sterne, Gabriel (2002), "Inflation Targets in the Global Context" in Norman Loayza and Raimundo Soto (eds.) Inflation Targeting: Design, Performance, Challenges, Central Bank of Chile.

von Hagen, Jurgen and Jizhong Zhou (2004), "The Choice of Exchange Rate Regime in Developing Countries: A Multinational Panel Analysis", CEPR Discussion Paper, No. 4227. 
Table 1: Benchmark OLS Inflation Results

\begin{tabular}{|l|c|c|c|c|}
\hline $\begin{array}{l}\text { De Jure Quant. } \\
\text { Monetary Target }\end{array}$ & $\begin{array}{c}-16.5 \\
(3.16)\end{array}$ & $\begin{array}{c}-20.8 \\
(3.02)\end{array}$ & & -16.8 \\
$(3.07)$
\end{tabular}

Regressand is inflation. Annual data, 1960-2000 for 40 countries.

OLS with robust standard errors in parentheses. Intercepts included but not tabulated.

Table 2: Sample Sensitivity

\begin{tabular}{|l|c|c|c|c|c|c|}
\hline & $\begin{array}{c}\text { Without } \\
\text { pre-1975 }\end{array}$ & $\begin{array}{c}\text { GDP p/c } \\
\text { at least } \\
\mathbf{\$ 5 , 0 0 0}\end{array}$ & $\begin{array}{c}\text { OECD } \\
\text { Only }\end{array}$ & $\begin{array}{c}\text { Without } \\
\text { outliers }\end{array}$ & $\begin{array}{c}\text { With } \\
\text { Argentina, } \\
\text { Brazil }\end{array}$ & $\begin{array}{c}\text { Without } \\
\text { High } \\
\text { Inflators }\end{array}$ \\
\hline De Jure Quant. & -15.1 & -12.1 & -5.8 & -13.2 & -77.2 & -3.11 \\
Monetary Target & $(2.6)$ & $(2.24)$ & $(1.8)$ & $(2.14)$ & $(21.2)$ & $(.98)$ \\
\hline Quant. Monetary & -4.14 & -4.88 & -4.6 & -5.69 & 11.2 & -3.57 \\
Success & $(.99)$ & $(1.02)$ & $(.67)$ & $(1.01)$ & $(6.78)$ & $(.53)$ \\
\hline Openness & -.017 & -.013 & .030 & -.019 & -.037 & -.015 \\
(\% GDP) & $. .009)$ & $(.008)$ & $(.014)$ & $(.007)$ & $(.04)$ & $(.004)$ \\
\hline Budget & -.61 & -.65 & -.26 & -.52 & -1.27 & -.13 \\
(\% GDP) & $(.25)$ & $(.17)$ & $(.06)$ & $(.15)$ & $(.99)$ & $(.04)$ \\
\hline BusCycle (Growth - & -.99 & -.53 & -.82 & -.45 & -5.69 & -.45 \\
Avg. Growth) & $(.75)$ & $(.20)$ & $(.27)$ & $(.18)$ & $(3.31)$ & $(.14)$ \\
\hline Log Real GDP p/c & -7.29 & -7.17 & -13.2 & -3.61 & -30.4 & -2.17 \\
& $(1.52)$ & $(1.33)$ & $(2.0)$ & $(.82)$ & $(9.73)$ & $(.42)$ \\
\hline Log Real GDP & -.97 & -1.11 & .52 & -1.16 & 12.3 & -.74 \\
& $(.56)$ & $(.50)$ & $(.37)$ & $(.42)$ & $(5.09)$ & $(.18)$ \\
\hline Observations & 817 & 989 & 699 & 1198 & 1232 & 1067 \\
\hline R $^{2}$ & .25 & .31 & .40 & .27 & .08 & .24 \\
\hline Regressan
\end{tabular}

Regressand is inflation. Annual data, 1960-2000 for 40 countries.

OLS with robust standard errors in parentheses. Intercepts included but not tabulated.

High Inflation countries are: Chile, Israel, Mexico, Turkey, and Uruguay. 
Table 3: Robustness Checks

\begin{tabular}{|l|c|c|c|c|c|}
\hline & $\begin{array}{c}\text { Country } \\
\text { Fixed } \\
\text { Effects }\end{array}$ & $\begin{array}{c}\text { Year Fixed } \\
\text { Effects }\end{array}$ & $\begin{array}{c}\text { Country, } \\
\text { Year } \\
\text { Effects }\end{array}$ & $\begin{array}{c}\text { Country, } \\
\text { Year } \\
\text { Effects }\end{array}$ & $\begin{array}{c}\text { Lead of } \\
\text { Inflation }\end{array}$ \\
\hline De Jure Quant. & -12.7 & -16.2 & -12.6 & -15.8 & -13.5 \\
Monetary Target & $(2.5)$ & $(2.2)$ & $(2.5)$ & $(3.5)$ & $(3.0)$ \\
\hline Quant. Monetary & -2.4 & -6.8 & -3.2 & .97 & -6.8 \\
Success & $(2.1)$ & $(2.0)$ & $(2.1)$ & $(1.85)$ & $(1.3)$ \\
\hline Openness & .16 & -.025 & .12 & .07 & -.02 \\
(\% GDP) & $(.04)$ & $(.014)$ & $(.04)$ & $(.06)$ & $(.01)$ \\
\hline Budget & -.55 & -.29 & -.41 & -.12 & -.82 \\
(\% GDP) & $(.15)$ & $(.14)$ & $(.16)$ & $(.17)$ & $(.31)$ \\
\hline BusCycle (Growth - & -1.26 & -.93 & -1.19 & -.41 & -.38 \\
Avg Growth) & $(.20)$ & $(.23)$ & $(.21)$ & $(.13)$ & $(.32)$ \\
\hline Log Real GDP p/c & -17.1 & -3.74 & -21.6 & 5.38 & -3.6 \\
\hline Log Real GDP & $(7.5)$ & $(1.33)$ & $(7.4)$ & $(16.8)$ & $(1.0)$ \\
\hline AR(1) Coefficient & 3.1 & -1.22 & 13.8 & -24.1 & -1.49 \\
\hline Observations & $(5.4)$ & $(.57)$ & $(6.4)$ & $(13.0)$ & $(.49)$ \\
\hline R $^{2}$ & 1200 & 1200 & 1200 & 1161 & 1203 \\
\hline Regr) & .09 & .19 & .06 & .01 & .20 \\
\hline
\end{tabular}

Regressand is inflation. Annual data, 1960-2000 for 40 countries.

OLS with robust standard errors in parentheses. Intercepts included but not tabulated.

Table 4: Dis-Aggregating Monetary Regimes

\begin{tabular}{|l|c|c|}
\hline De Jure Inflation & -20.2 & -13.2 \\
Target & $(2.5)$ & $(1.83)$ \\
\hline Inflation Target & 4.1 & \\
Success & $(1.9)$ & \\
\hline De Jure Money & -11.2 & -7.6 \\
Growth Target & $(2.7)$ & $(1.9)$ \\
\hline Money Growth Target & -2.43 & \\
Success & $(3.23)$ & \\
\hline De Jure Exchange Rate & -10.9 & -16.7 \\
Target & $(4.0)$ & $(2.3)$ \\
\hline Exchange Rate Target & -10.2 & \\
Success & $(2.7)$ & \\
\hline Openness & -.021 & -.027 \\
(\% GDP) & $(.009)$ & $(.009)$ \\
\hline Budget & -.47 & -.51 \\
(\% GDP) & $(.19)$ & $(.18)$ \\
\hline BusCycle (Growth - & -1.05 & -1.08 \\
Avg Growth) & $(.58)$ & $(.54)$ \\
\hline Log Real GDP p/c & -4.59 & -4.89 \\
& $(1.26)$ & $(1.19)$ \\
\hline Log Real GDP & -1.11 & -1.09 \\
& $(.51)$ & $(.47)$ \\
\hline Observations & 1023 & 1200 \\
\hline R & .18 & .17 \\
\hline Regrsand infliti & Ang & \\
\hline
\end{tabular}

Regressand is inflation. Annual data, 1960-2000 for 40 countries.

OLS with robust standard errors in parentheses. Intercepts included but not tabulated. 
Table 5: The Role of Political Stability

\begin{tabular}{|l|c|c|}
\hline $\begin{array}{l}\text { De Jure Quant. } \\
\text { Monetary Target }\end{array}$ & -16.4 & -16.5 \\
Quant. Monetary & -5.42 & $(3.1)$ \\
Success & $(1.05)$ & -5.45 \\
\hline Openness & -.024 & -.024 \\
(\% GDP) & $(.009)$ & $(.009)$ \\
\hline Budget & -.46 & -.46 \\
(\% GDP) & $(.17)$ & $(.17)$ \\
\hline BusCycle (Growth - & -1.03 & -1.04 \\
Avg Growth) & $(.54)$ & $(.53)$ \\
\hline Log Real GDP p/c & -4.43 & -4.80 \\
& $(1.18)$ & $(1.13)$ \\
\hline Log Real GDP & -1.45 & -1.34 \\
& $(.43)$ & $(.44)$ \\
\hline Revolutions & 1.86 & \\
\hline Coups & $(1.89)$ & -6.23 \\
\hline Observations & & $(2.65)$ \\
\hline R $^{2}$ & 1195 & 1197 \\
\hline
\end{tabular}

Regressand is inflation. Annual data, 1960-2000 for 40 countries unless noted.

OLS with robust standard errors in parentheses. Intercepts included but not tabulated.

Table 6: Instrumental Variable Results

\begin{tabular}{|l|c|c|c|c|c|c|c|c|}
\hline $\begin{array}{l}\text { Instrumental } \\
\text { variables }\end{array}$ & \multicolumn{3}{|c|}{ Political } & \multicolumn{3}{c|}{ Political and lagged regime } \\
\hline & $\begin{array}{c}\text { Bench- } \\
\text { mark }\end{array}$ & $\begin{array}{c}\text { Country } \\
\text { Fixed } \\
\text { Effects }\end{array}$ & $\begin{array}{c}\text { Year } \\
\text { Fixed } \\
\text { Effects }\end{array}$ & $\begin{array}{c}\text { Country, } \\
\text { Year } \\
\text { Effects }\end{array}$ & $\begin{array}{c}\text { Bench- } \\
\text { mark }\end{array}$ & $\begin{array}{c}\text { Country } \\
\text { Fixed } \\
\text { Effects }\end{array}$ & $\begin{array}{c}\text { Year } \\
\text { Fixed } \\
\text { Effects }\end{array}$ & $\begin{array}{c}\text { Country, } \\
\text { Year } \\
\text { Effects }\end{array}$ \\
\hline $\begin{array}{l}\text { De Jure Quant. } \\
\text { Monetary Target }\end{array}$ & -41.2 & -33.4 & -34.6 & -29.4 & -13.6 & -11.2 & -12.9 & -10.5 \\
$(16.9)$ & $(11.3)$ & $(16.3)$ & $(11.8)$ & $(3.2)$ & $(2.9)$ & $(2.6)$ & $(2.9)$ \\
\hline Quant. Monetary & -1.31 & 29.1 & -13.5 & 33.8 & -9.3 & -5.6 & -11.7 & -7.0 \\
Success & $(11.2)$ & $(12.3)$ & $(10.2)$ & $(19.8)$ & $(1.7)$ & $(3.1)$ & $(2.6)$ & $(3.2)$ \\
\hline Openness & -.02 & .14 & .002 & .10 & -.022 & .17 & -.019 & .13 \\
(\% GDP) & $(.009)$ & $(.06)$ & $(.02)$ & $(.06)$ & $(.008)$ & $(.05)$ & $(.014)$ & $(.05)$ \\
\hline Budget & -.393 & -.80 & -.20 & -.54 & -.47 & -.51 & -.31 & -.40 \\
$(\%$ GDP) & $(.161)$ & $(.21)$ & $(.16)$ & $(.21)$ & $(.17)$ & $(.16)$ & $(.14)$ & $(.16)$ \\
\hline BusCycle (Growth & -.86 & -1.56 & -.95 & -1.47 & -.99 & -1.29 & -.96 & -1.23 \\
- Avg Growth) & $(.53)$ & $(.25)$ & $(.26)$ & $(.27)$ & $(.55)$ & $(.21)$ & $(.24)$ & $(.22)$ \\
\hline Log Real GDP p/c & -2.64 & -35.7 & -.41 & -49.7 & -5.29 & -15.7 & -4.15 & -21.6 \\
& $(2.11)$ & $(15.5)$ & $(2.11)$ & $(20.2)$ & $(1.17)$ & $(8.2)$ & $(1.38)$ & $(8.2)$ \\
\hline Log Real GDP & -1.97 & 22.6 & -2.18 & 32.9 & -1.78 & .46 & -1.67 & 13.0 \\
& $(0.74)$ & $(13.6)$ & $(.74)$ & $(15.5)$ & $(.49)$ & $(6.2)$ & $(.60)$ & $(7.0)$ \\
\hline Observations & 1149 & 1149 & 1149 & 1149 & 1149 & 1149 & 1149 & 1149 \\
\hline R & 0.09 & .01 & .17 & .01 & .20 & .09 & .19 & .06 \\
\hline
\end{tabular}

Regressand is inflation. Annual data, 1960-2000 for 40 countries.

IV with robust standard errors in parentheses. Intercepts included but not tabulated.

Political instrumental variables for de jure quantitative monetary target and quantitative monetary success are: a) political constraints (Henisz); b) Presidential Electoral System (Persson-Tabellini); c) Majoritarian electoral system (Persson-Tabellini); d) Percentage of males over 25 years old with primary education (Barro-Lee); and e) Percentage of males over 25 years old with secondary education (Barro-Lee); 
Table 7: Using Five-Year Averaged Data

\begin{tabular}{|c|c|c|}
\hline & $\begin{array}{l}\text { De Jure Quantitative } \\
\text { Monetary Target }\left(\beta_{1}\right)\end{array}$ & $\begin{array}{c}\text { Quantitative Monetary } \\
\text { Target Hit }\left(\beta_{2}\right)\end{array}$ \\
\hline Benchmark & $\begin{array}{l}-11.8 \\
(4.4)\end{array}$ & $\begin{array}{l}-3.5 \\
(1.5)\end{array}$ \\
\hline Without pre-1975 & $\begin{array}{l}-10.8 \\
(4.2)\end{array}$ & $\begin{array}{l}-3.12 \\
(1.62)\end{array}$ \\
\hline GDP p/c at least $\$ 5,000$ & $\begin{array}{l}-11.4 \\
(4.7)\end{array}$ & $\begin{array}{l}-2.9 \\
(1.7)\end{array}$ \\
\hline Without Controls & $\begin{array}{l}-12.3 \\
(4.0)\end{array}$ & $\begin{array}{l}-3.5 \\
(1.3)\end{array}$ \\
\hline With Argentina, Brazil & $\begin{array}{l}-87.4 \\
(56.2)\end{array}$ & $\begin{array}{c}19.7 \\
(19.3)\end{array}$ \\
\hline Without High Inflators & $\begin{array}{l}-1.6 \\
(1.9)\end{array}$ & $\begin{array}{l}-4.24 \\
(1.15)\end{array}$ \\
\hline With Country Effects & $\begin{array}{l}-7.8 \\
(2.7)\end{array}$ & $\begin{array}{l}-2.5 \\
(2.1)\end{array}$ \\
\hline With Time Effects & $\begin{array}{l}-11.9 \\
(2.4)\end{array}$ & $\begin{array}{l}-3.8 \\
(2.2)\end{array}$ \\
\hline $\begin{array}{r}\text { With Time and Country } \\
\text { Effects }\end{array}$ & $\begin{array}{l}-7.9 \\
(2.6)\end{array}$ & $\begin{array}{l}-3.3 \\
(2.1)\end{array}$ \\
\hline $\begin{array}{l}\text { With Year and Country } \\
\text { Effects, } \operatorname{AR}(1) \text { Residual }\end{array}$ & $\begin{array}{l}-5.5 \\
(3.3)\end{array}$ & $\begin{array}{l}-2.4 \\
(2.6)\end{array}$ \\
\hline IV, Benchmark & $\begin{array}{l}-40.6 \\
(13.8)\end{array}$ & $\begin{array}{c}5.3 \\
(9.0)\end{array}$ \\
\hline $\begin{array}{r}\text { IV, Time and Country } \\
\text { Effects }\end{array}$ & $\begin{array}{l}-1.31 \\
(7.7)\end{array}$ & $\begin{array}{c}-5.0 \\
(12.8)\end{array}$ \\
\hline
\end{tabular}

Regressand is inflation. Data in 5-yr averages, derived from annual observations 1960-1999 for 40 countries.

Controls added but not recorded: openness; budget; business cycle growth deviation from mean; and logs of real GDP and real GDP per capita.

OLS with robust standard errors in parentheses. Intercepts included but not tabulated.

High Inflation countries are: Chile, Israel, Mexico, Turkey, and Uruguay.

Instrumental variables for de jure quantitative monetary target and quantitative monetary success the following political variables: a) political constraints (Henisz); b) Presidential Electoral System (Persson-Tabellini); and c) Majoritarian electoral system (Persson-Tabellini). d) Percentage of males over 25 years old with primary education (Barro-Lee); and e) Percentage of males over 25 years old with secondary education (Barro-Lee); 
Table 8: Effects of Regimes on Output Volatility: Benchmark Results.

\begin{tabular}{|l|c|c|c|c|c|}
\hline $\begin{array}{l}\text { De Jure Quant. } \\
\text { Monetary Target }\end{array}$ & $\begin{array}{c}.17 \\
(.35)\end{array}$ & $\begin{array}{c}-.18 \\
(.29)\end{array}$ & & $\begin{array}{c}.13 \\
(.51)\end{array}$ & $\begin{array}{c}-.56 \\
(.33)\end{array}$ \\
\hline Quant. Monetary & -.43 & & -.33 & -.55 & .33 \\
Success & $(.24)$ & & $(.22)$ & $(.31)$ & $(.26)$ \\
\hline Openness & -.002 & -.002 & -.002 & -.001 & \\
(\% GDP) & $(.002)$ & $(.002)$ & $(.002)$ & $(.002)$ & \\
\hline Budget & -.03 & -.03 & -.03 & -.03 & \\
(\% GDP) & $(.02)$ & $(.02)$ & $(.02)$ & $(.02)$ & \\
\hline Log Real GDP p/c & -.32 & -.31 & -.31 & -.24 & \\
& $(.18)$ & $(.18)$ & $(.17)$ & $(.19)$ & \\
\hline Log Real GDP & -.30 & -.27 & -.29 & -.37 & \\
& $(.08)$ & $(.08)$ & $(.08)$ & $(.10)$ & \\
\hline Lag of volatility & & & & .11 & \\
& & & & $(.08)$ & \\
\hline Observations & 211 & 211 & 211 & 153 & 237 \\
\hline $\mathbf{R}^{2}$ & .21 & .20 & .21 & .31 & .01 \\
\hline
\end{tabular}

Regressand is the average absolute value of the deviation of output growth from the mean growth rate. Data in 5-year averages derived from annual observations 1960-1999 for 40 countries. OLS with robust standard errors in parentheses. Intercepts included but not tabulated.

Table 9: Output Volatility; Robustness Checks.

\begin{tabular}{|l|c|c|c|c|c|}
\hline & $\begin{array}{c}\text { With } \\
\text { Argentina, } \\
\text { Brazil }\end{array}$ & $\begin{array}{c}\text { Without } \\
\text { High } \\
\text { Inflators }\end{array}$ & $\begin{array}{c}\text { With } \\
\text { time } \\
\text { effects }\end{array}$ & $\begin{array}{c}\text { With } \\
\text { country } \\
\text { effects }\end{array}$ & $\begin{array}{c}\text { With time } \\
\text { and } \\
\text { country } \\
\text { effects }\end{array}$ \\
\hline $\begin{array}{l}\text { De Jure Quant. } \\
\text { Monetary Target }\end{array}$ & -.07 & .61 & .14 & -.15 & .04 \\
\hline Quant. Monetary & $(.33)$ & $(.37)$ & $(.34)$ & $(.48)$ & $(.48)$ \\
Success & -.26 & -.46 & -.52 & .21 & .07 \\
\hline Openness & $(.23)$ & $(.25)$ & $(.25)$ & $(.38)$ & $(.40)$ \\
(\% GDP) & -.002 & -.001 & -.001 & -.012 & -.015 \\
Budget & $(.002)$ & $(.002)$ & $(.002)$ & $(.007)$ & $(.008)$ \\
(\% GDP) & -.03 & -.02 & -.03 & -.05 & -.07 \\
\hline Log Real GDP p/c & $(.02)$ & $(.02)$ & $(.02)$ & $(.02)$ & $(.02)$ \\
\hline Log Real GDP & -.45 & -.33 & -.24 & -.97 & -.78 \\
& $(.18)$ & $(.18)$ & $(.19)$ & $(1.11)$ & $(1.12)$ \\
\hline Observations & -.23 & -.27 & -.31 & .47 & 1.33 \\
\hline$R^{2}$ & $(.09)$ & $(.08)$ & $(.08)$ & $(.78)$ & $(.87)$ \\
\hline
\end{tabular}

Regressand is the average absolute value of the deviation of output growth from the mean growth rate. Data in 5-year averages derived from annual observations 1960-1999 for 40 countries.

OLS with robust standard errors in parentheses. Intercepts included but not tabulated 
Table 10: Output Volatility and Dis-Aggregated Monetary Regimes

\begin{tabular}{|l|c|c|}
\hline De Jure Inflation & -1.06 & -.40 \\
Target & $(.57)$ & $(.34)$ \\
\hline Inflation Target & .72 & \\
Success & $(.83)$ & \\
\hline De Jure Money & -.004 & .15 \\
Growth Target & $(.65)$ & $(.25)$ \\
\hline Money Growth Target & -.48 & \\
Success & $(1.15)$ & \\
\hline De Jure Exchange Rate & .93 & -.26 \\
Target & $(.81)$ & $(.23)$ \\
\hline Exchange Rate Target & -1.28 & \\
Success & $(.81)$ & \\
\hline Openness & -.002 & -.002 \\
(\% GDP) & $(.002)$ & $(.002)$ \\
\hline Budget & -.03 & -.03 \\
(\% GDP) & $(.02)$ & $(.02)$ \\
\hline Log Real GDP p/c & -.23 & -.29 \\
& $(.19)$ & $(.18)$ \\
\hline Log Real GDP & -.31 & -.30 \\
& $(.09)$ & $(.09)$ \\
\hline Observations & 182 & 211 \\
\hline R & .21 & .21 \\
\hline
\end{tabular}

Regressand is the average absolute value of the deviation of output growth from the mean growth rate.

Data in 5-year averages derived from annual observations 1960-1999 for 40 countries.

OLS with robust standard errors in parentheses. Intercepts included but not tabulated

Table 11: Effects of policy regime on output volatility. Instrumental Variable Results

\begin{tabular}{|l|c|c|c|c|}
\hline Instrumental Variables & Political & Political & $\begin{array}{c}\text { Political, } \\
\text { Lags }\end{array}$ & $\begin{array}{c}\text { Political, } \\
\text { Lags }\end{array}$ \\
\hline & & $\begin{array}{c}\text { Country, } \\
\text { Year } \\
\text { Effects }\end{array}$ & $\begin{array}{c}\text { Country, } \\
\text { Year } \\
\text { Effects }\end{array}$ \\
\hline De Jure Quant. & .56 & -1.8 & .19 & .82 \\
Monetary Target & $(1.85)$ & $(1.5)$ & $(.54)$ & $(1.3)$ \\
\hline Quant. Monetary & -1.24 & -.58 & -.67 & -.10 \\
Success & $(1.85)$ & $(2.5)$ & $(.43)$ & $(1.1)$ \\
\hline Openness & -.001 & -.01 & -.001 & -.005 \\
(\% GDP) & $(.002)$ & $(.01)$ & $(.002)$ & $(.01)$ \\
\hline Budget & -.02 & -.06 & -.03 & -.08 \\
(\% GDP) & $(.02)$ & $(.03)$ & $(.02)$ & $(.03)$ \\
\hline Log Real GDP p/c & -.30 & 1.17 & -.22 & -2.94 \\
\hline Log Real GDP & $(.22)$ & $(2.41)$ & $(.19)$ & $(2.12)$ \\
\hline Observations & -.36 & -.10 & -.43 & 2.40 \\
\hline R $^{2}$ & $(.11)$ & $(1.75)$ & $(.10)$ & $(1.55)$ \\
\hline Regrs) & 202 & 202 & 147 & 147 \\
\hline
\end{tabular}

Regressand is the average absolute value of the deviation of output growth from the mean growth rate.

Data in 5-year averages derived from annual observations 1960-1999 for 40 countries. IV with robust standard errors in parentheses. Intercepts included but not tabulated. Instrumental variables for de jure quantitative monetary target and quantitative monetary success are: a) political constraints (Henisz); b) Presidential Electoral System (Persson-Tabellini); c) Majoritarian electoral system (Persson-Tabellini) d) Percentage of males over 25 years old with primary education (Barro-Lee); and e) Percentage of males over 25 years old with secondary education (BarroLee); "Lags" adds: d) lag of de jure quantitative monetary target; and e) lag of quantitative monetary success. 
Table 12: Volatility from Different Trend Models

\begin{tabular}{|l|c|c|c|c|c|c|}
\hline & $\begin{array}{c}\text { HP- } \\
\text { Filtered }\end{array}$ & $\begin{array}{c}\text { HP- } \\
\text { Filtered }\end{array}$ & $\begin{array}{c}\text { Decadal } \\
\text { Deviations }\end{array}$ & $\begin{array}{c}\text { Decadal } \\
\text { Deviations }\end{array}$ & $\begin{array}{c}\text { Decadal } \\
\text { Std. Dev. }\end{array}$ & $\begin{array}{c}\text { Decadal } \\
\text { Std. Dev. }\end{array}$ \\
\hline De Jure Quant. & OLS & IV & OLS & IV & OLS & IV \\
Monetary Target & .23 & 2.95 & .33 & 3.54 & .65 & 5.80 \\
\hline Quant. Monetary & $.43)$ & $(2.19)$ & $(.46)$ & $(1.64)$ & $.70)$ & $(2.47)$ \\
Success & -.72 & -3.33 & -.57 & -2.36 & -.94 & -3.74 \\
\hline Openness & $(.31)$ & $(1.32)$ & $(.34)$ & $(1.16)$ & $(.56)$ & $(1.81)$ \\
(\% GDP) & .003 & .004 & .001 & .001 & .002 & .002 \\
Budget & $(.002)$ & $(.002)$ & $(.002)$ & $(.002)$ & $(.002)$ & $(.003)$ \\
(\% GDP) & -.05 & -.04 & -.04 & -.04 & -.06 & -.06 \\
\hline Log Real GDP p/c & $(.02)$ & $(.03)$ & $(.02)$ & $(.03)$ & $(.02)$ & $(.04)$ \\
\hline Log Real GDP & -.35 & -.49 & -.13 & -.30 & -.17 & -.43 \\
& $(.18)$ & $(.27)$ & $(.19)$ & $(.26)$ & $(.24)$ & $(.37)$ \\
\hline Observations & -.24 & -.42 & -.32 & -.40 & -.43 & -.53 \\
\hline$R^{2}$ & $(.11)$ & $(.15)$ & $(.11)$ & $(.14)$ & $(.15)$ & $(.21)$ \\
\hline
\end{tabular}

Regressand is: a) average absolute value of the deviation of real GDP from HP-filtered real GDP (in logs), b) average absolute value of deviation of output growth from a ten-year average growth rate, or c) decadal standard deviation of output growth.

Data derived from annual observations 1960-1999 for 40 countries.

OLS/IV with robust standard errors in parentheses. Intercepts included but not tabulated.

Instrumental variables for de jure quantitative monetary target and quantitative monetary success are: a) political constraints (Henisz); b) Presidential Electoral System (Persson-Tabellini); c) Majoritarian electoral system (PerssonTabellini); d) Percentage of males over 25 years old with primary education (Barro-Lee); and e) Percentage of males over 25 years old with secondary education (Barro-Lee); 


\section{Appendix 1: Growth}

We briefly turn in passing to the effects of the monetary policy regime on economic growth. This question has been an issue of heated debate. The most recent evidence on the issue comes from the paper of Levi-Yeyati and Sturzenegger (2003) who document that in a large set of countries a fixed exchange rate regime leads to lower economic growth. To address this question in our data set we use as a benchmark model following specification:

$$
\begin{aligned}
\Delta \mathrm{y}_{\mathrm{it}}= & \beta_{1} \text { DJTarget }_{\mathrm{it}}+\beta_{2} \text { Success }_{\mathrm{it}} \\
& +\gamma_{1} \text { Open }_{\mathrm{it}}+\gamma_{2} \text { GovSpend }_{\mathrm{it}-1}+\gamma_{3} \text { GDPpc }_{\mathrm{it}-1}+\gamma_{4} \text { PopGR }_{\mathrm{it}-1}+\gamma_{4} \text { Secondary }_{\mathrm{it}-1}+\varepsilon_{\mathrm{it}}
\end{aligned}
$$

where i denotes a country, $\mathrm{t}$ denotes a five-year period, and $\mathrm{t}-1$ denotes the average over the previous (non-overlapping) five-year period. The other variables are:

- $\Delta y$ denotes the five-year average growth rate of country i calculated from annual data

- DJTarget ${ }_{t}$ is a dummy variable that is one if the country had a quantitative monetary policy target during period $t$, and zero otherwise,

- $\gamma_{\mathrm{i}}$ is a set of nuisance coefficients,

- Success is a dummy variable that is one if the country hit its de jure quantitative target during $\mathrm{t}$, and zero otherwise,

- Open is trade (exports plus imports) as a percentage of GDP,

- GovSpend is government spending as a percentage of GDP,

- GDPpc is the natural logarithm of real GDP per capita from the previous five-year period,

- PopGR is the growth rate of population

- Secondary is the percentage of males over 25 years old with completed secondary degree of education

- $\varepsilon$ is a well-behaved residual term for all other growth determinants. 
The specification of the controls in the growth regression is standard. The initial GDP per capita is expected to have a negative sign under the conditional convergence hypothesis, openness should enter with a positive sign as more open economies are expected to grow faster (Frankel and Romer, 1999), higher government spending will slow down economic growth, which implies a negative sign for $\gamma_{2}$; population growth can be positively correlated with real growth and negatively with the growth rate of real GDP per capita; and, education is expected to be positively correlated with output growth. We have decided to use again five-year averages because most of the theories cited above refer to long-term growth rates and the five-year average seems to be the shortest period for which one can reasonably argue that the variables capture long-term growth rates.

Table A1 starts with the benchmark results in the first column. The first coefficient of interest, which captures the effect of an explicit target on growth, is insignificant statistically and it implies that the economic impact of an explicit target is negligible. The success in implementing the target is negative, but again insignificant. Although the fit of the regression is relatively good with an $\mathrm{R}^{2}$ of $50 \%$, it seems that neither having, not hitting the target affects economic growth in our sample of countries.

In Table A2, we report some standard robustness checks. In general we do not find much evidence to support a claim that monetary targets affect growth positively or negatively. Only when time effects are included in the regression, there is some evidence that having a target is significant the $5 \%$ level.

Overall we find some evidence that the having an explicit target leads to faster economic growth, but we quickly point out that this evidence is quite fragile and most of the time insignificant at conventional levels. 
Table A1: Policy Regime and Growth: Benchmark Results.

\begin{tabular}{|c|c|c|c|c|}
\hline $\begin{array}{l}\text { De Jure Quant. } \\
\text { Monetary Target }\end{array}$ & $\begin{array}{l}1.28 \\
(.81)\end{array}$ & $\begin{array}{l}1.01 \\
(.72)\end{array}$ & & $\begin{array}{l}-1.13 \\
(.62)\end{array}$ \\
\hline $\begin{array}{l}\text { Quant. Monetary } \\
\text { Success }\end{array}$ & $\begin{array}{l}-.40 \\
(.52)\end{array}$ & & $\begin{array}{l}.20 \\
(.50)\end{array}$ & $\begin{array}{l}2.33 \\
(.55)\end{array}$ \\
\hline $\begin{array}{l}\text { Log Real GDP p/c } \\
\text { (lagged) }\end{array}$ & $\begin{array}{l}-2.24 \\
(.61)\end{array}$ & $\begin{array}{l}-2.18 \\
(.61)\end{array}$ & $\begin{array}{l}-2.28 \\
(.61)\end{array}$ & \\
\hline $\begin{array}{l}\text { Openness } \\
\text { (\% GDP) }\end{array}$ & $\begin{array}{c}.01 \\
(.003)\end{array}$ & $\begin{array}{c}.01 \\
(.003)\end{array}$ & $\begin{array}{c}.01 \\
(.002)\end{array}$ & \\
\hline $\begin{array}{l}\text { Government } \\
\text { spending } \\
\text { (\% GDP, lagged) }\end{array}$ & $\begin{array}{l}-.03 \\
(.02)\end{array}$ & $\begin{array}{l}-.038 \\
(.020)\end{array}$ & $\begin{array}{l}-.03 \\
(.02)\end{array}$ & \\
\hline Population growth & $\begin{array}{l}.06 \\
(.40)\end{array}$ & $\begin{array}{l}.05 \\
(.40)\end{array}$ & $\begin{array}{l}.09 \\
(.40)\end{array}$ & \\
\hline $\begin{array}{l}\text { Percentage of males } \\
\text { with secondary } \\
\text { school (lagged) }\end{array}$ & $\begin{array}{c}.01 \\
(.02)\end{array}$ & $\begin{array}{c}.01 \\
(.02)\end{array}$ & $\begin{array}{c}.02 \\
(.02)\end{array}$ & \\
\hline Observations & 106 & 106 & 106 & 237 \\
\hline $\mathbf{R}^{2}$ & .50 & .50 & .48 & .08 \\
\hline
\end{tabular}

Regressand is the average growth rate of output over five-year periods.

Data in 5-year averages derived from annual observations 1960-1999 for 42 countries.

OLS with robust standard errors in parentheses. Intercepts included but not tabulated.

Table A2: Policy Regime and Growth: Robustness Checks.

\begin{tabular}{|l|c|c|c|c|c|}
\hline & $\begin{array}{c}\text { With } \\
\text { Argentina, } \\
\text { Brazil }\end{array}$ & $\begin{array}{c}\text { Without } \\
\text { High } \\
\text { Inflators }\end{array}$ & $\begin{array}{c}\text { With } \\
\text { time } \\
\text { effects }\end{array}$ & $\begin{array}{c}\text { With } \\
\text { country } \\
\text { effects }\end{array}$ & $\begin{array}{c}\text { With time } \\
\text { and } \\
\text { country } \\
\text { effects }\end{array}$ \\
\hline $\begin{array}{l}\text { De Jure Quant. } \\
\text { Monetary Target }\end{array}$ & 1.27 & .73 & 1.51 & -.003 & .04 \\
\hline Quant. Monetary & -.39 & $(.73)$ & $(.74)$ & $(.85)$ & $(.78)$ \\
Success & $(.52)$ & $(.51)$ & -.29 & .52 & .38 \\
\hline $\begin{array}{l}\text { Log Real GDP p/c } \\
\text { (lagged) }\end{array}$ & -2.23 & -2.37 & -2.51 & -2.80 & $(.69)$ \\
\hline $\begin{array}{l}\text { Openness } \\
\text { (\% GDP) }\end{array}$ & $(.61)$ & $(.59)$ & $(.52)$ & $(1.06)$ & $(1.32)$ \\
\hline $\begin{array}{l}\text { Government } \\
\text { spending } \\
\text { (\% GDP, lagged) }\end{array}$ & $(.014$ & .014 & .014 & .05 & .05 \\
\hline Population growth &. .03 & $(.003)$ & $(.003)$ & $(.02)$ & $.02)$ \\
\hline Percentage of males &. .03 & -.05 & .02 & -.02 \\
with secondary & $(.01$ & $(.02)$ & $(.02)$ & $(.04)$ & $(.05)$ \\
school (lagged) & $(.01)$ & $(.01)$ & $(.012)$ & $(.04)$ & $(.03)$ \\
\hline Observations & 108 & 103 & 106 & 137 & 137 \\
\hline$R^{2}$ & .50 & .53 & .58 & .37 & .45 \\
\hline
\end{tabular}

Regressand is the average growth rate of output over five-year (non-overlapping) periods.

Data in 5-year averages derived from annual observations 1960-1999 for 42 countries.

OLS with robust standard errors in parentheses. Intercepts included but not tabulated 


\section{Appendix 2: Adding Inflation Volatility}

We briefly investigate the effect of monetary policy regimes on inflation volatility. The key results are reported in Table A3. Inflation volatility is calculated over five-year periods, and the rest of the data are also averaged over non-overlapping 5-year periods (so as to conform to the calculation of inflation volatility). Table A3 is a modified version of Table 1 in which baseline regressions are estimated twice - with and without the level of inflation as a regressor.

Is there any effect of regimes on the volatility of inflation above and beyond the wellknown correlation between the level and the variance of inflation? Our results suggest that although the de jure regime does have a small negative effect on inflation volatility, this effect disappears once the level of inflation is included as a regressor. We interpret this as indicating that countries with explicit targets have lower inflation (as we have documented above) and lower inflation is also less volatile inflation. Thus the main effect of regimes goes through the level of inflation. This result is also robust to various specification changes.

Table A3: Inflation Volatility as Dependent Variable

\begin{tabular}{|l|c|c|}
\hline $\begin{array}{l}\text { De Jure Quant. } \\
\text { Monetary Target }\end{array}$ & $\begin{array}{c}-104.7 \\
(67.1)\end{array}$ & $\begin{array}{c}-.4 \\
(18.3)\end{array}$ \\
\hline Quant. Monetary & 12.5 & 43.8 \\
Success & $(21.9)$ & $(30.2)$ \\
\hline Openness & .01 & .13 \\
(\% GDP) & $(.08)$ & $(.11)$ \\
\hline Budget & -2.8 & .2 \\
(\% GDP) & $(1.8)$ & $(.8)$ \\
\hline BusCycle (Growth - & -7.6 & -1.7 \\
Avg Growth) & $(6.3)$ & $(3.6)$ \\
\hline Log Real GDP p/c & -33.4 & -8.0 \\
& $(19.0)$ & $(7.3)$ \\
\hline Log Real GDP & 7.3 & 10.8 \\
& $(9.6)$ & $(8.9)$ \\
\hline Inflation & & 8.8 \\
& & $(4.3)$ \\
\hline Observations & 208 & 208 \\
\hline R $^{2}$ & .13 & .48 \\
\hline
\end{tabular}

Regressand is inflation volatility. Five-year averaged data, 1960-2000 for 42 countries OLS with robust standard errors in parentheses. Intercepts included but not tabulated. 


\section{Appendix 3: Post-1982 Sample}

Table A4: Benchmark OLS Inflation Results, post-1982

\begin{tabular}{|l|c|c|c|c|}
\hline $\begin{array}{l}\text { De Jure Quant. } \\
\text { Monetary Target }\end{array}$ & $\begin{array}{c}-10.8 \\
(2.1)\end{array}$ & $\begin{array}{c}-12.7 \\
(1.9)\end{array}$ & & -12.4 \\
$(2.1)$
\end{tabular}

Regressand is inflation. Annual data, 1983-2000 for 40 countries.

OLS with robust standard errors in parentheses. Intercepts included but not tabulated.

Table A5: Sample Sensitivity of post-1982 Results

\begin{tabular}{|l|c|c|c|c|c|}
\hline & $\begin{array}{c}\text { GDP p/c } \\
\text { at least } \\
\mathbf{\$ 5 , 0 0 0}\end{array}$ & $\begin{array}{c}\text { OECD } \\
\text { only }\end{array}$ & $\begin{array}{c}\text { Without } \\
\text { outliers }\end{array}$ & $\begin{array}{c}\text { With } \\
\text { Argentina, } \\
\text { Brazil }\end{array}$ & $\begin{array}{c}\text { Without } \\
\text { High } \\
\text { Inflators }\end{array}$ \\
\hline De Jure Quant. & -11.7 & -4.4 & -10.8 & -88.6 & -2.6 \\
Monetary Target & $(2.4)$ & $(1.6)$ & $(2.1)$ & $(28.7)$ & $(.96)$ \\
\hline Quant. Monetary & -2.6 & -2.5 & -3.0 & 23.0 & -3.2 \\
Success & $(1.1)$ & $(.75)$ & $(1.0)$ & $(10.4)$ & $(.55)$ \\
\hline Openness & -.01 & .024 & -.01 & -.03 & -.02 \\
(\% GDP) & $(.01)$ & $(.018)$ & $(.01)$ & $(.09)$ & $(.004)$ \\
\hline Budget & -.77 & .40 & -.68 & -1.03 & -.10 \\
(\% GDP) & $(.32)$ & $(.19)$ & $(.27)$ & $(2.30)$ & $(.05)$ \\
\hline BusCycle (Growth - & -.29 & -.51 & -.25 & -10.5 & -.07 \\
Avg. Growth) & $(.37)$ & $(.57)$ & $(.33)$ & $(7.6)$ & $(.13)$ \\
\hline Log Real GDP p/c & -10.8 & -32.5 & -8.8 & -63.7 & -4.5 \\
& $(1.8)$ & $(4.5)$ & $(1.5)$ & $(20.8)$ & $(.62)$ \\
\hline Log Real GDP & .28 & 1.80 & .14 & 27.4 & -.56 \\
& $(.74)$ & $(.58)$ & $(.70)$ & $(10.2)$ & $(.21)$ \\
\hline Observations & 505 & 318 & 559 & 584 & 491 \\
\hline R $^{2}$ & 0.32 & .63 & 0.32 & 0.10 & 0.39 \\
\hline
\end{tabular}

Regressand is inflation. Annual data, 1983-2000 for 40 countries.

OLS with robust standard errors in parentheses. Intercepts included but not tabulated.

High Inflation countries are: Chile, Israel, Mexico, Turkey, and Uruguay. 
Table A6: Decade by Decade Inflation Results, using Benchmark OLS

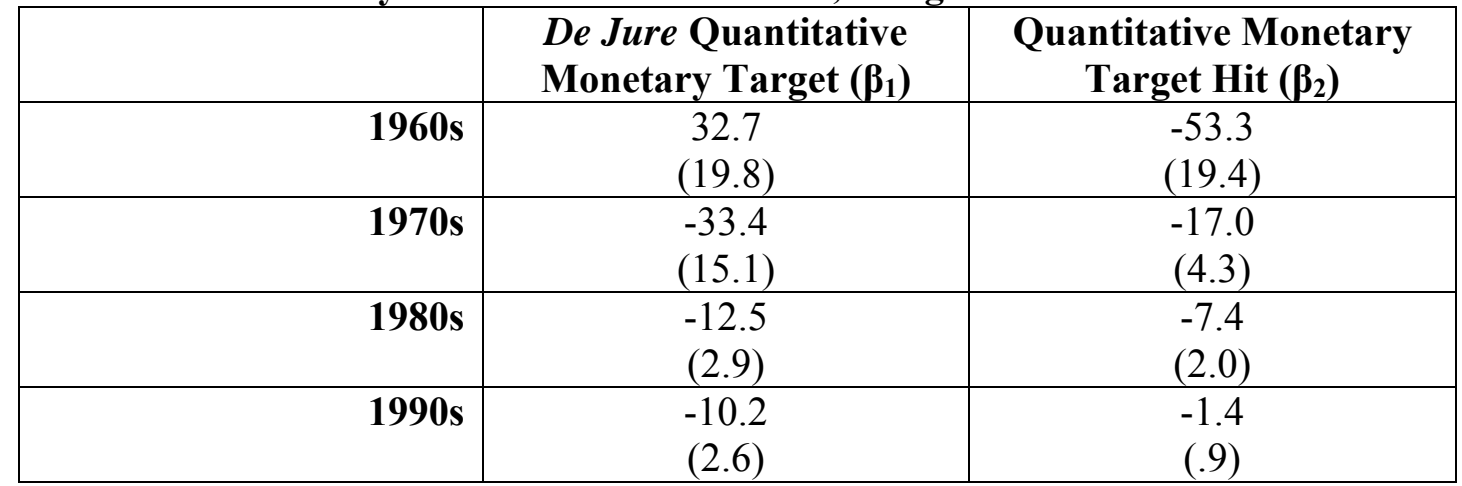

Regressand is inflation. Annual observations for individual decades for 40 countries.

Controls added but not recorded: openness; budget; business cycle growth deviation from mean; and logs of real GDP and real GDP per capita.

OLS with robust standard errors in parentheses. Intercepts included but not tabulated. 


\section{Appendix 4: Classification of Monetary Policy Regimes}

\section{Exchange Rate Targets}

Data on exchange rate regimes comes from Reinhart and Rogoff (2004), downloaded from Carmen Reinhart's web site. The de jure classification is based on the official IMF classification. We label all observations as having an exchange rate target with the exception of those in the category "freely floating." The de facto classification is based on the ReinhartRogoff "natural" classification. Additional materials are available at Carmen Reinhart's web site for detailed analysis of each of the countries.

\section{Sources for Inflation and Money Growth Targets}

The data on inflation and money targets comes from different sources. Our main references are Cottarelli and Giannini (1997) (CG) for all regimes, and Mishkin and Schmidt-Hebbel (2002) (MS) for inflation targets. In addition, for developed countries, we also use Agenor (2002). Other general references for inflation and money targets are Sterne (2002), Siklos (1999) and Bernanke, Laubach, Mishkin and Posen (1999). For recent years, web sites of the corresponding central bank have also been used as confirmation. In some cases, there are disagreements about the sources on the starting year (especially for money growth targets).

\section{Inflation Targets}

There are few cases of disagreement on the years where inflation targets were present. There are some minor disagreements on the exact month were the policy was started (and in those cases we make a judgement call). The same is true for the ranges set for the inflation target that we use to assess whether the target was hit or not. The biggest complication is to define a range when a single point is used as a target. In some cases we take the single number as maximum and set a range for $0 \%$ to that number. We do this when there is clear evidence that the central bank is trying to reduce inflation. In some other cases we set a band around this central point. We look for a historical reference within the same central bank to establish the size of the band (for example, a band set in previous years or in the years that follow). In the absence of any historical reference, we use $+/-1 \%$.

\section{Money Targets}

The classification of money targeters is more difficult, since there are a number of central banks that use money aggregates as "references" but cannot be properly considered as having a target for money (for the same reason that most central banks use inflation forecasts but we have not included them as targeting inflation). We do not wish to be too strict because we want to base our classification as much as possible on the words used by central banks, not on their actions, given that we also check whether targets have been met or not. We collect as much information as possible on each of the central banks and make a judgement call on whether or not the central bank had a target for a monetary aggregate that was meaningful. Where appropriate, we note issues in comments below the tables that follow. 


\section{De jure Classifications of Monetary Policy Regimes}

\begin{tabular}{|l|l|l|l|l|}
\hline Argentina & & Exchange Rate & Inflation & Money \\
\hline & $1960-1978$ & Yes & No & No \\
\hline & 1979 & Yes & No & Yes \\
\hline & $1979-1988$ & Yes & No & No \\
\hline & $1989-1990$ & No & No & No \\
\hline & $1990-2000$ & Yes & No & No \\
\hline
\end{tabular}

Comments: Money target was in place in 1979 according to CG who claims "the central bank announced the commitment to monitor the attainment of the announced (credit) targets".

\begin{tabular}{|l|l|l|l|l|}
\hline Australia & & Exchange Rate & Inflation & Money \\
\hline & $1960-1975$ & Yes & No & No \\
\hline & $1976-1983$ & Yes & No & Yes \\
\hline & 1984 & No & No & Yes \\
\hline & $1985-1992$ & No & No & No \\
\hline & $1993-2000$ & No & Yes & No \\
\hline
\end{tabular}

Comments: Monetary targeting starts in March 1976 and finishes in January 1985. Source: CG, Edey (1997) and

Reserve Bank of Australia Bulletin (October 1997). Inflation targeting starts in January 1993. Range for inflation is $2-3 \%$.

\begin{tabular}{|l|l|l|l|l|}
\hline Austria & & Exchange Rate & Inflation & Money \\
\hline & $1960-1998$ & Yes & No & No \\
\hline & $1999-2000$ & No & Yes & Yes \\
\hline
\end{tabular}

Comments: After 1999, Austria becomes part of EMU so policies are ECB policies.

\begin{tabular}{|l|l|l|l|l|}
\hline Belgium & & Exchange Rate & Inflation & Money \\
\hline & $1960-1998$ & Yes & No & No \\
\hline & $1999-2000$ & No & Yes & Yes \\
\hline
\end{tabular}

Comments: After 1999, Belgium becomes part of EMU so policies are ECB policies.

\begin{tabular}{|l|l|l|l|l|}
\hline Botswana & & Exchange Rate & Inflation & Money \\
\hline & $1960-1969$ & Yes & No & No \\
\hline
\end{tabular}

\begin{tabular}{|l|l|l|l|l|}
\hline Brazil & & Exchange Rate & Inflation & Money \\
\hline & $1960-1976$ & Yes & No & No \\
\hline & 1977 & Yes & No & Yes \\
\hline & $1978-1989$ & Yes & No & No \\
\hline & $1990-1993$ & No & No & No \\
\hline & $1994-1998$ & Yes & No & No \\
\hline & $1999-2000$ & No & Yes & No \\
\hline
\end{tabular}

Comments: In 1997 Brazil adopts a money target on top of the exchange rate target (source: CG). Inflation targeting starts in June 1999. Source for inflation target and range: MS.

\begin{tabular}{|l|l|l|l|l|}
\hline Canada & & Exchange Rate & Inflation & Money \\
\hline & $1960-1969$ & Yes & No & No \\
\hline & $1970-1975$ & No & No & No \\
\hline
\end{tabular}




\begin{tabular}{|l|l|l|l|l|}
\hline & $1976-1982$ & No & No & Yes \\
\hline & $1983-1990$ & No & No & No \\
\hline & $1991-2000$ & No & Yes & No \\
\hline
\end{tabular}

Comments: Money target first announced in November 1975 and dropped in November 1982. Sources: CG, Reserve Bank of Australia Bulletin (October 1997). Inflation targeting starts in February 1991. Source for inflation target and range: MS.

\begin{tabular}{|l|l|l|l|l|}
\hline Chile & & Exchange Rate & Inflation & Money \\
\hline & $1960-1961$ & Yes & No & No \\
\hline & $1962-1964$ & No & No & No \\
\hline & $1965-1990$ & Yes & No & No \\
\hline & $1991-1999$ & Yes & Yes & No \\
\hline & 2000 & No & Yes & No \\
\hline
\end{tabular}

Comments: Inflation targeting starts in January 1991 (Source: MS). Single point ranges replace range for inflation in the period $1995-2000$. We add a range of $+/-1 \%$ to those years, which is consistent with the range that existed prior to 1994 (and also the range in place for 2001).

\begin{tabular}{|l|l|l|l|l|}
\hline Colombia & & Exchange Rate & Inflation & Money \\
\hline & $1960-1992$ & Yes & No & No \\
\hline & $1993-1998$ & Yes & No & Yes \\
\hline & 1999 & No & No & Yes \\
\hline & 2000 & No & Yes & Yes \\
\hline
\end{tabular}

Comments: Years for money targeting from: CG (Target announced in November 1992) and Informe de Inflacion, Central Bank of Colombia (recent years). Inflation target adopted in September 1999. We interpret the target of 10\% as a maximum (consistent with inflation reports by central bank).

\begin{tabular}{|l|l|l|l|l|}
\hline Costa Rica & & Exchange Rate & Inflation & Money \\
\hline & $1960-1991$ & Yes & No & No \\
\hline & $1992-1994$ & No & No & No \\
\hline & $1995-2000$ & Yes & No & No \\
\hline
\end{tabular}

\begin{tabular}{|l|l|l|l|l|}
\hline Denmark & & Exchange Rate & Inflation & Money \\
\hline & $1960-2000$ & Yes & No & No \\
\hline
\end{tabular}

\begin{tabular}{|l|l|l|l|l|}
\hline Finland & & Exchange Rate & Inflation & Money \\
\hline & $1960-1991$ & Yes & No & No \\
\hline & 1992 & No & No & No \\
\hline & $1993-1995$ & No & Yes & No \\
\hline & $1996-1998$ & Yes & Yes & No \\
\hline & $1999-2000$ & No & Yes & Yes \\
\hline
\end{tabular}

Comments: Starting date for inflation targeting is February 1993 (source: MS). After 1999, Finland becomes part of EMU so policies are ECB policies. For the targets before 1999 we interpret $2 \%$ as a maximum, which is consistent with the way we interpret ECB policies after 1999.

\begin{tabular}{|l|l|l|l|l|}
\hline France & & Exchange Rate & Inflation & Money \\
\hline & $1960-1976$ & Yes & No & No \\
\hline & $1977-1998$ & Yes & No & Yes \\
\hline
\end{tabular}




\begin{tabular}{|l|l|l|l|l|}
\hline & $1999-2000$ & No & Yes & Yes \\
\hline
\end{tabular}
policies are ECB policies.

\begin{tabular}{|l|l|l|l|l|}
\hline Germany & & Exchange Rate & Inflation & Money \\
\hline & $1960-1970$ & Yes & No & No \\
\hline & 1971 & No & No & No \\
\hline & $1972-1974$ & Yes & No & No \\
\hline & $1975-1998$ & Yes & No & Yes \\
\hline & $1999-2000$ & No & Yes & Yes \\
\hline
\end{tabular}

Comments: After 1999, Germany becomes part of EMU so policies are ECB policies.

\begin{tabular}{|l|l|l|l|l|}
\hline Greece & & Exchange Rate & Inflation & Money \\
\hline & $1960-1969$ & Yes & No & No \\
\hline & $1970-1994$ & Yes & No & Yes \\
\hline & $1995-1999$ & Yes & No & No \\
\hline & $1999-2000$ & No & Yes & Yes \\
\hline
\end{tabular}

Comments: Source for Money target years: CG. After 1999, Greece becomes part of EMU so policies are ECB policies.

\begin{tabular}{|l|l|l|l|l|}
\hline Hong Kong & & Exchange Rate & Inflation & Money \\
\hline & $1960-2000$ & Yes & No & No \\
\hline
\end{tabular}

\begin{tabular}{|l|l|l|l|l|}
\hline Ireland & & Exchange Rate & Inflation & Money \\
\hline & $1960-1998$ & Yes & No & No \\
\hline & $1999-2000$ & No & Yes & Yes \\
\hline
\end{tabular}

Comments: After 1999, Ireland becomes part of EMU so policies are ECB policies.

\begin{tabular}{|l|l|l|l|l|}
\hline Israel & & Exchange Rate & Inflation & Money \\
\hline & $1960-1976$ & Yes & No & No \\
\hline & $1977-1984$ & No & No & No \\
\hline & $1985-1991$ & Yes & No & No \\
\hline & $1992-2000$ & Yes & Yes & No \\
\hline
\end{tabular}

Comments: Inflation target adopted in January 1992 (source: MS). We add a range of $+/-1 \%$ added in years where single point range is announced, which is consistent with the years where the band was explicit.

\begin{tabular}{|l|l|l|l|l|}
\hline Italy & & Exchange Rate & Inflation & Money \\
\hline & $1960-1971$ & Yes & No & No \\
\hline & $1972-1973$ & No & No & No \\
\hline & $1974-1978$ & No & No & Yes \\
\hline & $1979-1991$ & Yes & No & Yes \\
\hline & $1992-1995$ & No & No & Yes \\
\hline & $1996-1998$ & Yes & No & Yes \\
\hline & $1999-2000$ & No & Yes & Yes \\
\hline
\end{tabular}

Comments: Source for Money target years: CG and annual reports Bank of Italy. After 1999, Italy becomes part of EMU so policies are ECB policies. 


\begin{tabular}{|l|l|l|l|l|}
\hline Japan & & Exchange Rate & Inflation & Money \\
\hline & $1960-1972$ & Yes & No & No \\
\hline & $1973-2000$ & No & No & No \\
\hline
\end{tabular}

\begin{tabular}{|l|l|l|l|l|}
\hline Korea & & Exchange Rate & Inflation & Money \\
\hline & $1960-1978$ & Yes & No & No \\
\hline & $1979-1996$ & Yes & No & Yes \\
\hline & 1997 & No & No & Yes \\
\hline & $1998-2000$ & No & Yes & Yes \\
\hline
\end{tabular}

Comments: Source: CG (until 1994) and document "Monetary Policy in Korea" (Bank of Korea). Money stopped being a target in 2001. Notice that from 1997 onwards the monetary aggregate that was targeted was changed and that there was a double domestic target (inflation and money) "based on the ECB". Range for inflation target from MS and confirmed by web site of Bank of Korea.

\begin{tabular}{|l|l|l|l|l|}
\hline Malaysia & & Exchange Rate & Inflation & Money \\
\hline & $1960-1997$ & Yes & No & No \\
\hline & 1998 & No & No & No \\
\hline & $1999-2000$ & Yes & No & No \\
\hline
\end{tabular}

\begin{tabular}{|l|l|l|l|l|}
\hline Mauritius & & Exchange Rate & Inflation & Money \\
\hline & $1960-1997$ & Yes & No & No \\
\hline & $1998-2000$ & No & No & No \\
\hline
\end{tabular}

\begin{tabular}{|l|l|l|l|l|}
\hline Mexico & & Exchange Rate & Inflation & Money \\
\hline & $1960-1993$ & Yes & No & No \\
\hline & $1994-1998$ & No & No & No \\
\hline & $1999-2000$ & No & Yes & No \\
\hline
\end{tabular}

Comments: Date of adoption of inflation target is January 1999 (source: MS). Point targets interpreted as maximum.

\begin{tabular}{|l|l|l|l|l|}
\hline Netherlands & & Exchange Rate & Inflation & Money \\
\hline & $1960-1998$ & Yes & No & No \\
\hline & $1999-2000$ & No & Yes & Yes \\
\hline
\end{tabular}

Comments: After 1999, the Netherlands becomes part of EMU so policies are ECB policies.

\begin{tabular}{|l|l|l|l|l|}
\hline New Zealand & & Exchange Rate & Inflation & Money \\
\hline & $1960-1983$ & Yes & No & No \\
\hline & $1984-1989$ & No & No & No \\
\hline & $1990-2000$ & No & Yes & No \\
\hline
\end{tabular}

Comments: Date of adoption inflation target is March 1990 (source: MS).

\begin{tabular}{|l|l|l|l|l|}
\hline Norway & & Exchange Rate & Inflation & Money \\
\hline & $1960-1991$ & Yes & No & No \\
\hline & $1992-1994$ & No & No & No \\
\hline & $1995-2000$ & Yes & No & No \\
\hline
\end{tabular}

\begin{tabular}{|l|l|l|l|l|}
\hline Panama & Exchange Rate & Inflation & Money \\
\hline
\end{tabular}




\begin{tabular}{|c|c|c|c|c|}
\hline & $1960-2000$ & Yes & No & No \\
\hline \multirow[t]{4}{*}{ Paraguay } & & Exchange Rate & Inflation & Money \\
\hline & 1960-1989 & Yes & No & No \\
\hline & 1990-1997 & No & No & No \\
\hline & $1998-2000$ & No & No & Yes \\
\hline \multirow[t]{3}{*}{ Portugal } & & Exchange Rate & Inflation & Money \\
\hline & 1960-1998 & Yes & No & No \\
\hline & $1999-2000$ & No & Yes & Yes \\
\hline
\end{tabular}

Comments: After 1999, Portugal becomes part of EMU so policies are ECB policies.

\begin{tabular}{|l|l|l|l|l|}
\hline Singapore & & Exchange Rate & Inflation & Money \\
\hline & $1960-1962$ & No & No & No \\
\hline & $1963-2000$ & Yes & No & No \\
\hline
\end{tabular}

\begin{tabular}{|l|l|l|l|l|}
\hline South Africa & & Exchange Rate & Inflation & Money \\
\hline & $1960-1982$ & Yes & No & No \\
\hline & $1983-1985$ & No & No & No \\
\hline & $1986-1999$ & No & No & Yes \\
\hline & 2000 & No & Yes & No \\
\hline
\end{tabular}

Comments: Money targets replaced by Inflation targeting in February 2000 (Source: CG until 1994 complemented for recent years with document named "Monetary Policy in South Africa" downloaded from the web site of the SA Central Bank).

\begin{tabular}{|l|l|l|l|l|}
\hline Spain & & Exchange Rate & Inflation & Money \\
\hline & $1960-1973$ & Yes & No & No \\
\hline & $1974-1975$ & No & No & No \\
\hline & $1976-1977$ & Yes & No & No \\
\hline & $1978-1983$ & Yes & No & Yes \\
\hline & $1984-1988$ & No & No & Yes \\
\hline & $1989-1994$ & Yes & No & Yes \\
\hline & $1995-1998$ & Yes & Yes & No \\
\hline & $1999-2000$ & No & Yes & Yes \\
\hline
\end{tabular}

Comments: Source for money target years is CG and Sterne (Bank of England, 2000) who confirm that the Bank of Spain dropped money targets in 1994 and adopted inflation targets in 1995 ("a new framework based on inflation targeting was announced in January 1995”). After 1999, Spain becomes part of EMU so policies are ECB policies. Source for inflation target and range: MS.

\begin{tabular}{|l|l|l|l|l|}
\hline Sweden & & Exchange Rate & Inflation & Money \\
\hline & $1960-1992$ & Yes & No & No \\
\hline & $1993-2000$ & Yes & Yes & No \\
\hline
\end{tabular}

Comments: Date of adoption inflation target is January 1993 (source: MS).

\begin{tabular}{|l|l|l|l|l|}
\hline Switzerland & & Exchange Rate & Inflation & Money \\
\hline & $1960-1972$ & Yes & No & No \\
\hline & $1973-1974$ & No & No & No \\
\hline
\end{tabular}




\begin{tabular}{|l|l|l|l|l|}
\hline & $1975-1977$ & No & No & Yes \\
\hline & 1978 & Yes & No & Yes \\
\hline & 1979 & Yes & No & No \\
\hline & $1980-1981$ & Yes & No & Yes \\
\hline $1982-1999$ & No & No & Yes \\
\hline & 2000 & No & Yes & No \\
\hline
\end{tabular}

Comments: Source for Money target years: CG, Rich (JME 1997) and Annual reports Bank of Switzerland. Annual target was put in place in 1975 and abandoned in the Fall of 1978. Reinstated later in 1980 and replaced in 1990 by medium-term targets for 5 year periods. Inflation target starts in January 2000. Source for inflation target and range: MS and confirmed by Central Bank web site.

\begin{tabular}{|l|l|l|l|l|}
\hline Thailand & & Exchange Rate & Inflation & Money \\
\hline & $1960-1996$ & Yes & No & No \\
\hline & $1997-1999$ & No & No & No \\
\hline & 2000 & No & Yes & No \\
\hline
\end{tabular}

Comments: Inflation target adopted in April 2000. Source for inflation target and range: MS.

\begin{tabular}{|l|l|l|l|l|}
\hline Trin\&Tob. & & Exchange Rate & Inflation & Money \\
\hline & $1960-1969$ & No & No & No \\
\hline
\end{tabular}

\begin{tabular}{|l|l|l|l|l|}
\hline Tunisia & & Exchange Rate & Inflation & Money \\
\hline & $1960-2000$ & Yes & No & No \\
\hline
\end{tabular}

\begin{tabular}{|l|l|l|l|l|}
\hline Turkey & & Exchange Rate & Inflation & Money \\
\hline & $1960-1989$ & Yes & No & No \\
\hline & $1990-1992$ & Yes & No & Yes \\
\hline & $1993-2000$ & Yes & No & No \\
\hline
\end{tabular}

Comments: Source for Money target years: CG and Sterne, who confirms that it was abandoned during 1992.

\begin{tabular}{|l|l|l|l|l|}
\hline Uruguay & & Exchange Rate & Inflation & Money \\
\hline & 1960 & No & No & No \\
\hline & 1961 & Yes & No & No \\
\hline & $1962-1963$ & No & No & No \\
\hline & 1964 & Yes & No & No \\
\hline & 1965 & No & No & No \\
\hline & $1966-1969$ & Yes & No & No \\
\hline & $1970-1973$ & Yes & No & Yes \\
\hline & $1974-1981$ & Yes & No & No \\
\hline & $1982-1985$ & No & No & No \\
\hline & $1986-1989$ & No & No & Yes \\
\hline & $1990-1992$ & No & No & No \\
\hline & $1993-2000$ & Yes & No & No \\
\hline
\end{tabular}

Comments: Source for Money target years: CG.

\begin{tabular}{|l|l|l|l|l|}
\hline UK & & Exchange Rate & Inflation & Money \\
\hline & $1960-1971$ & Yes & No & No \\
\hline
\end{tabular}




\begin{tabular}{|l|l|l|l|l|}
\hline & $1972-1976$ & No & No & No \\
\hline & $1977-1990$ & No & No & Yes \\
\hline & $1991-1992$ & Yes & No & Yes \\
\hline & $1993-1996$ & No & Yes & Yes \\
\hline & $1997-2000$ & No & Yes & No \\
\hline
\end{tabular}

Comments: Source for money target years Edey, Reserve Bank of Australia Bulletin, October 1996 and Sterne, Band of England. Inflation target starting in October 1992 (source: MS). We use a range of $+/-1 \%$ around central inflation target.

\begin{tabular}{|l|l|l|l|l|}
\hline USA & & Exchange Rate & Inflation & Money \\
\hline & $1960-1972$ & Yes & No & No \\
\hline & $1973-1974$ & No & No & No \\
\hline & $1975-1995$ & No & No & Yes \\
\hline & $1996-2000$ & No & No & No \\
\hline
\end{tabular}

Comments: Source for Money target years: CG and annual reports Federal Reserve. After reading annual reports, the word "Target" stops appearing in the 1996 report so we pick 1995 as a .

\begin{tabular}{|l|l|l|l|l|}
\hline Venezuela & & Exchange Rate & Inflation & Money \\
\hline & $1960-1988$ & Yes & No & No \\
\hline & $1989-1993$ & No & No & No \\
\hline & $1994-2000$ & Yes & No & No \\
\hline
\end{tabular}




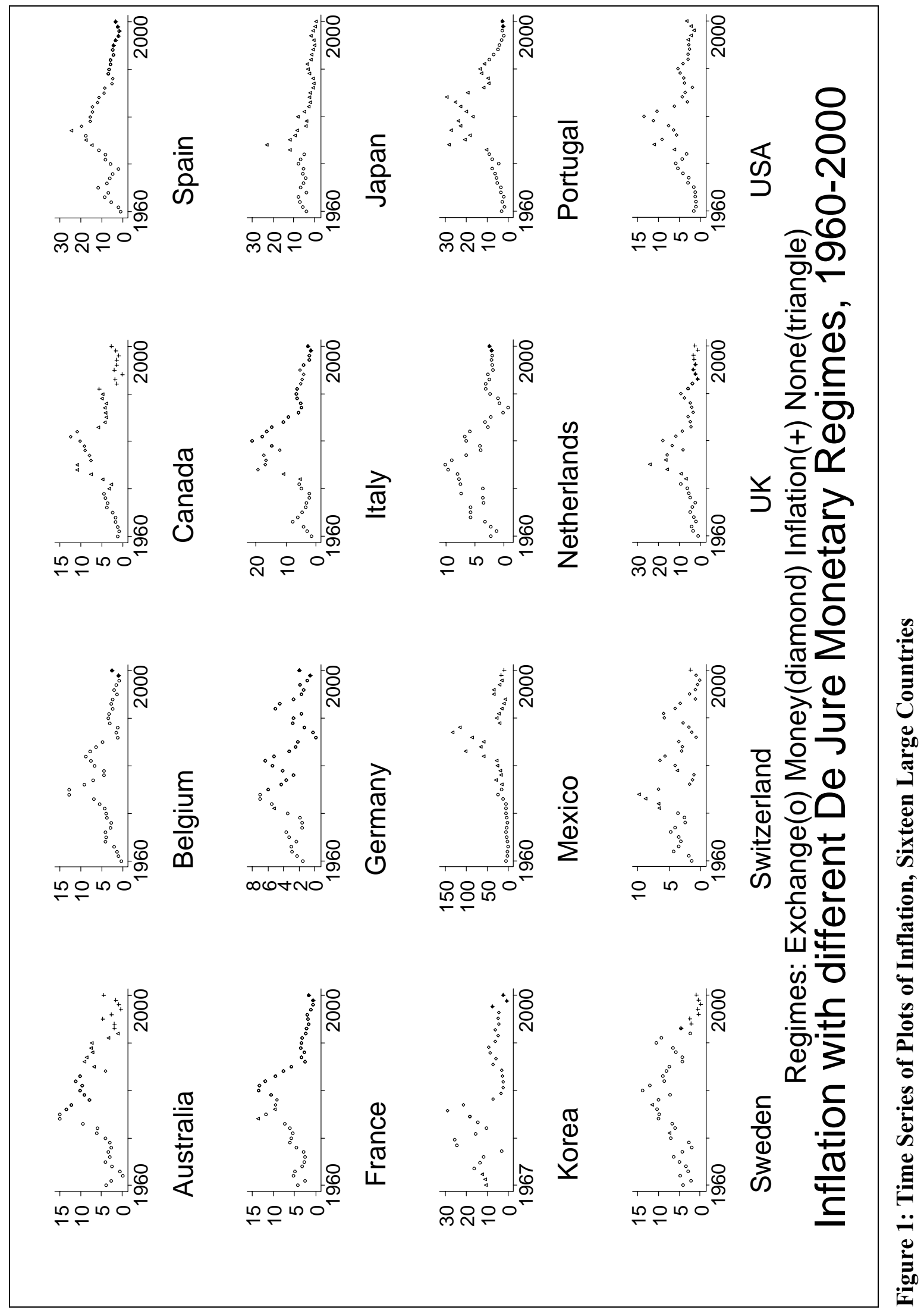




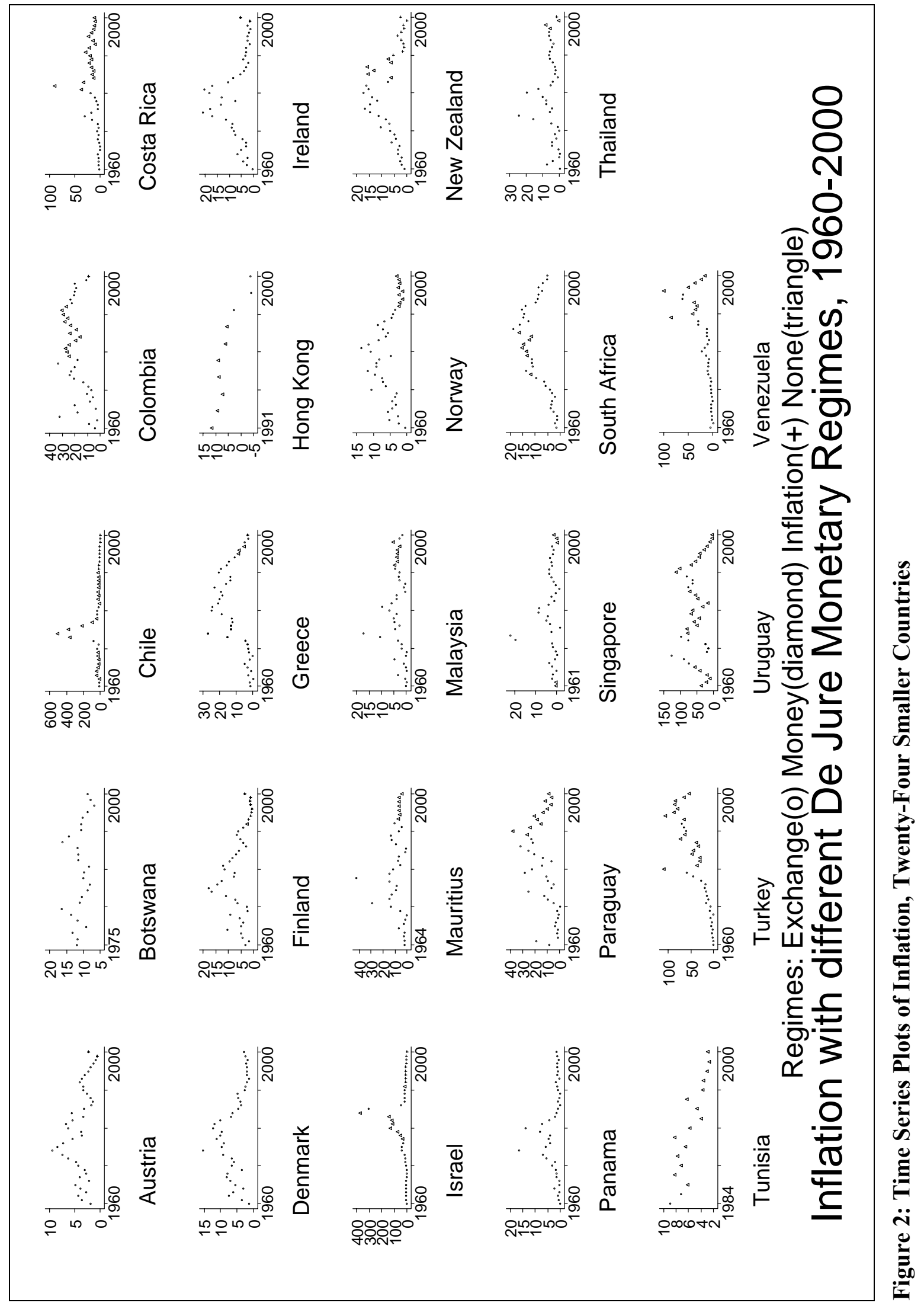




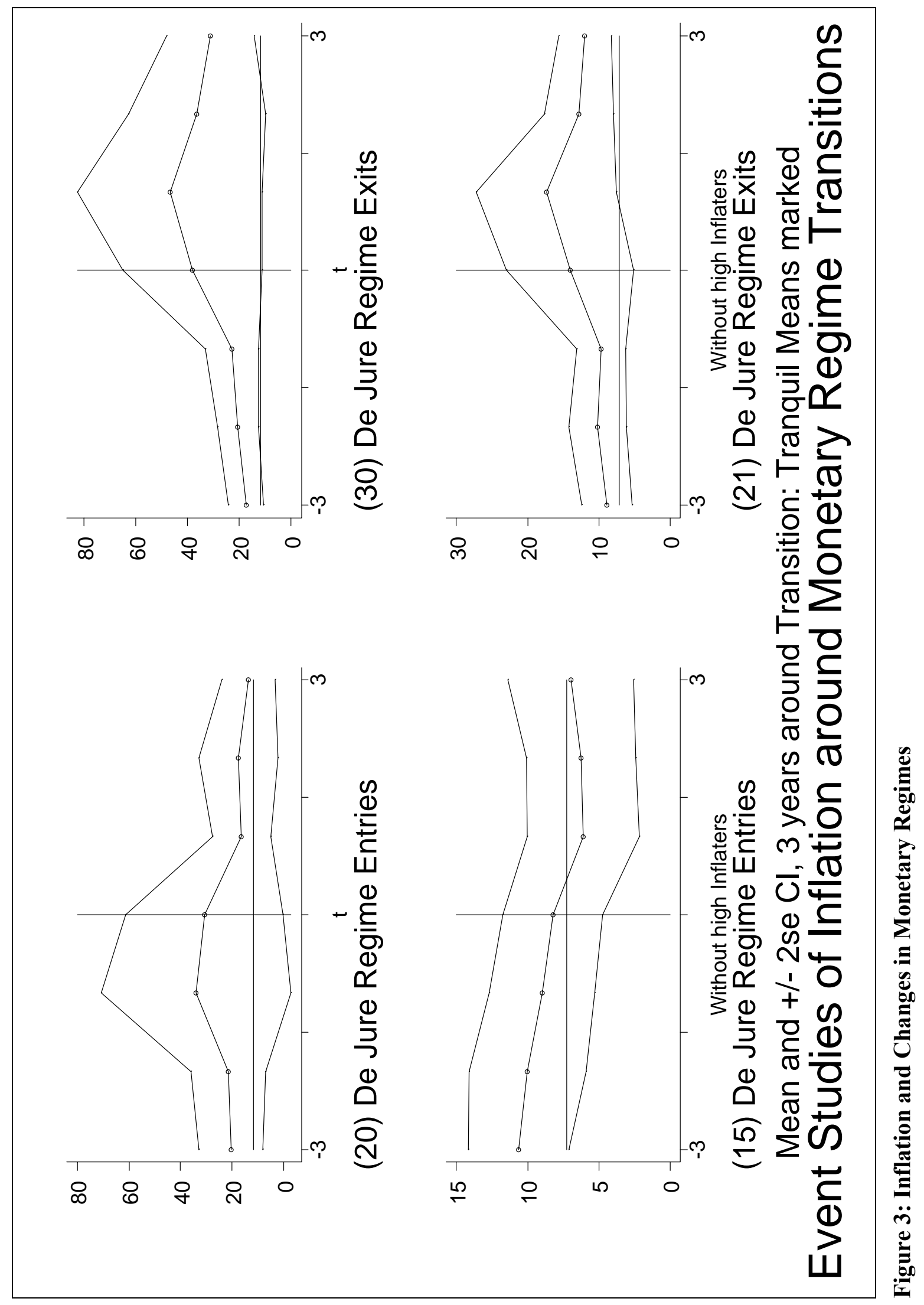




\section{European Central Bank Working Paper Series}

For a complete list of Working Papers published by the ECB, please visit the ECB's website (http://www.ecb.int)

570 "Household debt sustainability: what explains household non-performing loans? An empirical analysis" by L. Rinaldi and A. Sanchis-Arellano, January 2006.

57I “Are emerging market currency crises predictable? A test” by T. A. Peltonen, January 2006.

572 "Information, habits, and consumption behavior: evidence from micro data" by M. Kuismanen and L. Pistaferri, January 2006.

573 "Credit chains and the propagation of financial distress" by F. Boissay, January 2006.

574 "Inflation convergence and divergence within the European Monetary Union" by F. Busetti, L. Forni, A. Harvey and F. Venditti, January 2006.

575 "Growth in euro area labour quality" by G. Schwerdt and J. Turunen, January 2006.

576 “Debt stabilizing fiscal rules” by P. Michel, L. von Thadden and J.-P. Vidal, January 2006.

577 “Distortionary taxation, debt, and the price level” by A. Schabert and L. von Thadden, January 2006.

578 "Forecasting ECB monetary policy: accuracy is (still) a matter of geography" by H. Berger, M. Ehrmann and M. Fratzscher, January 2006.

579 "A disaggregated framework for the analysis of structural developments in public finances" by J. Kremer, C. Rodrigues Braz, T. Brosens, G. Langenus, S. Momigliano and M. Spolander, January 2006.

580 "Bank interest rate pass-through in the euro area: a cross country comparison" by C. K. Sørensen and T. Werner, January 2006.

$58 \mathrm{I}$ "Public sector efficiency for new EU Member States and emerging markets" by A. Afonso, L. Schuknecht and V. Tanzi, January 2006.

582 "What accounts for the changes in U.S. fiscal policy transmission?" by F. O. Bilbiie, A. Meier and G. J. Müller, January 2006.

583 “Back to square one: identification issues in DSGE models" by F. Canova and L. Sala, January 2006.

584 “A new theory of forecasting” by S. Manganelli, January 2006.

585 "Are specific skills an obstacle to labor market adjustment? Theory and an application to the EU enlargement” by A. Lamo, J. Messina and E. Wasmer, February 2006.

586 "A method to generate structural impulse-responses for measuring the effects of shocks in structural macro models” by A. Beyer and R. E. A. Farmer, February 2006. 
587 "Determinants of business cycle synchronisation across euro area countries" by U. Böwer and C. Guillemineau, February 2006.

588 "Rational inattention, inflation developments and perceptions after the euro cash changeover" by M. Ehrmann, February 2006.

589 "Forecasting economic aggregates by disaggregates" by D. F. Hendry and K. Hubrich, February 2006.

590 "The pecking order of cross-border investment" by C. Daude and M. Fratzscher, February 2006.

591 "Cointegration in panel data with breaks and cross-section dependence" by $A$. Banerjee and J. L. Carrion-i-Silvestre, February 2006.

592 "Non-linear dynamics in the euro area demand for MI" by A. Calza and A. Zaghini, February 2006.

593 “Robustifying learnability” by R. J. Tetlow and P. von zur Muehlen, February 2006.

594 “The euro's trade effects” by R. Baldwin, comments by J. A. Frankel and J. Melitz, March 2006.

595 "Trends and cycles in the euro area: how much heterogeneity and should we worry about it?" by D. Giannone and L. Reichlin, comments by B. E. Sørensen and M. McCarthy, March 2006.

596 "The effects of EMU on structural reforms in labour and product markets" by R. Duval and J. Elmeskov, comments by S. Nickell and J. F. Jimeno, March 2006.

597 "Price setting and inflation persistence: did EMU matter?" by I. Angeloni, L. Aucremanne, M. Ciccarelli, comments by W. T. Dickens and T. Yates, March 2006.

598 "The impact of the euro on financial markets" by L. Cappiello, P. Hördahl, A. Kadareja and S. Manganelli, comments by X. Vives and B. Gerard, March 2006.

599 "What effects is EMU having on the euro area and its Member Countries? An overview" by F. P. Mongelli and J. L. Vega, March 2006.

600 “A speed limit monetary policy rule for the euro area” by L. Stracca, April 2006.

601 "Excess burden and the cost of inefficiency in public services provision" by A. Afonso and V. Gaspar, April 2006.

602 "Job flow dynamics and firing restrictions: evidence from Europe" by J. Messina and G. Vallanti, April 2006.

603 “Estimating multi-country VAR models" by F. Canova and M. Ciccarelli, April 2006.

604 "A dynamic model of settlement" by T. Koeppl, C. Monnet and T. Temzelides, April 2006.

605 “(Un)Predictability and macroeconomic stability” by A. D’Agostino, D. Giannone and P. Surico, April 2006.

606 "Measuring the importance of the uniform nonsynchronization hypothesis" by D. A. Dias, C. Robalo Marques and J. M. C. Santos Silva, April 2006. 
607 "Price setting behaviour in the Netherlands: results of a survey" by M. Hoeberichts and A. Stokman, April 2006.

608 "How does information affect the comovement between interest rates and exchange rates?" by M. Sánchez, April 2006.

609 "The elusive welfare economics of price stability as a monetary policy objective: why New Keynesian central bankers should validate core inflation" by W. H. Buiter, April 2006.

610 "Real-time model uncertainty in the United States: the Fed from 1996-2003" by R. J. Tetlow and B. Ironside, April 2006.

611 "Monetary policy, determinacy, and learnability in the open economy" by J. Bullard and E. Schaling, April 2006.

612 "Optimal fiscal and monetary policy in a medium-scale macroeconomic model" by S. Schmitt-Grohé and M. Uribe, April 2006.

613 "Welfare-based monetary policy rules in an estimated DSGE model of the US economy" by M. Juillard, P. Karam, D. Laxton and P. Pesenti, April 2006.

614 "Expenditure switching vs. real exchange rate stabilization: competing objectives for exchange rate policy" by M. B. Devereux and C. Engel, April 2006.

615 "Quantitative goals for monetary policy" by A. Fatás, I. Mihov and A. K. Rose, April 2006. 
